\title{
Carbon footprinting of universities worldwide: Part I-objective comparison by standardized metrics
}

\author{
Eckard Helmers $^{1 *}$ (D), Chia Chien Chang ${ }^{2}$ and Justin Dauwels ${ }^{3}$
}

\begin{abstract}
Background: Universities, as innovation drivers in science and technology worldwide, should be leading the Great Transformation towards a carbon-neutral society and many have indeed picked up the challenge. However, only a small number of universities worldwide are collecting and publishing their carbon footprints, and some of them have defined zero emission targets. Unfortunately, there is limited consistency between the reported carbon footprints (CFs) because of different analysis methods, different impact measures, and different target definitions by the respective universities.

Results: Comprehensive CF data of 20 universities from around the globe were collected and analysed. Essential factors contributing to the university CF were identified. For the first time, CF data from universities were not only compared. The CF data were also evaluated, partly corrected, and augmented by missing contributions, to improve the consistency and comparability. The CF performance of each university in the respective year is thus homogenized, and measured by means of two metrics: $\mathrm{CO}_{2}$ e emissions per capita and per $\mathrm{m}^{2}$ of constructed area. Both metrics vary by one order of magnitude across the different universities in this study. However, we identified ten universities reaching a per capita carbon footprint of lower than or close to $1.0 \mathrm{Mt}$ (metric tons) $\mathrm{CO}_{2} \mathrm{e} /$ person and year (normalized by the number of people associated with the university), independent from the university's size. In addition to the aforementioned two metrics, we suggested a new metric expressing the economic efficiency in terms of the CF per $\$$ expenditures and year. We next aggregated the results for all three impact measures, arriving at an overall carbon performance for the respective universities, which we found to be independent of geographical latitude. Instead the per capita measure correlates with the national per capita CFs, and it reaches on average $23 \%$ of the national impacts per capita. The three top performing universities are located in Switzerland, Chile, and Germany.

Conclusion: The usual reporting of $\mathrm{CO}_{2}$ emissions is categorized into Scopes 1-3 following the GHG Protocol Corporate Accounting Standard which makes comparison across universities challenging. In this study, we attempted to standardize the CF metrics, allowing us to objectively compare the CF at several universities. From this study, we observed that, almost 30 years after the Earth Summit in Rio de Janeiro (1992), the results are still limited. Only one zero emission university was identified, and hence, the transformation should speed up globally.

Keywords: Carbon footprinting, University sustainability, University carbon footprint, Higher education institutions, Per capita carbon footprint, Zero emission university, Carbon offsetting, Greenhouse gas emissions, GHG accounting and reporting, Energy impacts, Mobility impacts
\end{abstract}

*Correspondence: e.helmers@umwelt-campus.de

1 Dep. of Environ. Planning and Technology, University of Applied

Sciences Trier, Umwelt-Campus, PO box 1380, 55761 Birkenfeld, Germany

Full list of author information is available at the end of the article

\section{Introduction}

This contribution discusses and evaluates the sustainability of the institutions that are the origin of sciences: the universities. We like to hypothesize that particularly

\section{Springer Open}

(c) The Author(s) 2021. This article is licensed under a Creative Commons Attribution 4.0 International License, which permits use, sharing, adaptation, distribution and reproduction in any medium or format, as long as you give appropriate credit to the original author(s) and the source, provide a link to the Creative Commons licence, and indicate if changes were made. The images or other third party material in this article are included in the article's Creative Commons licence, unless indicated otherwise in a credit line to the material. If material is not included in the article's Creative Commons licence and your intended use is not permitted by statutory regulation or exceeds the permitted use, you will need to obtain permission directly from the copyright holder. To view a copy of this licence, visit http://creativeco mmons.org/licenses/by/4.0/. 
universities emphasizing sustainability actions might inspire scientists engaged in sustainability research, and will qualify engineers engaged in seeking sustainable practise. Hence, it should be essential to develop sustainable universities from every point of view. The institutional sustainability of a university has been quantified and evaluated by a variety of research attempts, like as, e.g., sustainability contents in university education [1]. In this article, however, we understand and analyse university sustainability as a technical term, with respect to $\mathrm{CO}_{2}$-equivalent emissions of campuses.

Universities began to pick up sustainability problems early: The COPERNICUS University Charter for Sustainable Development in 1993 is seen as "a response to the Earth Summit in Rio de Janeiro (in 1992) and marked a breakthrough in raising consciousness within the European universities" [2]. Following this, several international networks were founded to foster sustainable development at higher education institutions (HEI) by conferences, awards, etc. (e.g., the ISCN International sustainable campus network, [3]. Often sustainability in higher education institutions (HEI) has been interpreted as a management attempt (e.g., [4]) rather than a quantitative effect.

\section{Analysing the ecological footprint of higher education institutions (HEI)}

Quantifying the environmental impact of a university often suffers from the problem that consumption and impact data are not recorded regularly and/or without sufficient depth of data. This problem has been alleviated by the method of Environmentally Extended Input Output Analysis (EEIOA) operating with financial data provided by the universities purchasing departments (e.g., [5]). Financial data are then converted by certain factors resulting in land footprints (for six different land types available, see [6]). Emissions such as $\mathrm{CO}_{2}$ are converted into a certain value of land consumption. EEIOA requires much recalculation, and accordingly, it comes with an additional uncertainty [7]. We stay away from this method and quantify a direct consumption-based CF. Although the CF is just one metric, it is the most discussed aspect of a university's ecological footprint. Less commonly, other footprints have been quantified like the nitrogen impact of a campus [8].

\section{University carbon footprinting: global status quo}

In the scientific community, there is a broad discussion about the necessity and the potential of universities to become "carbon-neutral" (e.g., [9]). Nevertheless, only a small minority of universities are currently recording and publishing comprehensive carbon inventories, while those published in local languages may not be easily available for international comparison (e.g., the one from the University of Potsdam [10], is published in German). Clearly, university carbon footprinting is most institutionalized in USA, where almost 1,000 HEIs have registered to use the Stars Reporting Tool [11]. Around half of these institutions are being rated based on their performance in emissions and documentation. Stars [11] is listing just one university from outside North America with a gold award, the university college of Cork (Ireland), which has been included in this investigation. The gold award in this grading system indicates that all data necessary to compile a full GHG (greenhouse gas) emission inventory have been submitted. The biggest advantage of reporting systems such as Stars [11] certainly is the attempt to make data internationally comparable, transparent, and available which is essentially needed when transforming and tracking the global economy towards a more climate friendly situation or preferably towards zero carbon emissions, while this target so far may miss a commonly agreed definition [12]. To enable a transparent international inter-comparison, Stars [11] is for example reporting basic specifications of university campuses $\left(\mathrm{CO}_{2} \mathrm{e}\right.$ emissions by sector, no. of students and staff, the energy intensive space of a campus, etc.). Because the system is "self-reporting", no critical evaluation may be expected. The publication of standardized raw emission data, however, generates an important kind of transparency.

Outside such carbon reporting schemes, there are plenty of sustainability initiatives established among HEIs worldwide, some of them institutionalized like university rankings. However, many of these initiatives mainly focus on management aspects, climate action in general, and scientific activity around sustainability subjects, thus serving as advertisement and marketing platforms within the global competition for students and projects (e.g. [13, 14]).

In Europe, most universities that publish complete carbon footprints seem to be located in Great Britain. In fact, the British government encourages HEIs to report CFs [15]. In Germany, there seems to be a few universities only quantifying their institutional $\mathrm{CO}_{2}$ emissions in detail like the University of Potsdam [10] and the dedicated zero carbon emission Leuphana University Lüneburg [16], which describes itself as being the "first climate-neutral university worldwide without purchasing certificates" [17]. Umwelt-Campus Birkenfeld (UCB), although marketed as a "Zero emission university" [18], did not publish a complete carbon balance so far, this is presented here for the first time.

A literature search for universities publishing CFs from Scandinavia and France failed, as also, for example, in the "motherland" of the Kyoto protocol, Japan. 
This investigation is not meant as a quantitative report on universities publishing CFs worldwide; however, it aims to deliver an overview on activities, current methodology, and the magnitude of CFs caused by universities worldwide. Nevertheless, we believe that the map in Fig. 1 delivers a representation of university activities worldwide. Presently, there is an agglomeration of such activities in western Europe and particularly in North America, besides these two regions, there are a few universities scattered worldwide that are particularly engaged on this field.

\section{GHG protocol corporate accounting and reporting standard}

Almost all universities who report $\mathrm{CO}_{2}$ emissions are following a scheme given by the "GHG Protocol Corporate Accounting and Reporting Standard" [19]. Although the allocation of impacts due to this scheme is simple (Scope 1: impacts caused by internal infrastructure, Scope 2: purchased energy; Scope 3: everything other, usually upstream activity impacts), many universities partly deviate from this scheme and apply individual allocations. On top of that, the single most important impact (energy consumption) usually belongs to Scope 2; however, big universities are running their own power plants (here: University College of Cork, Monash University,

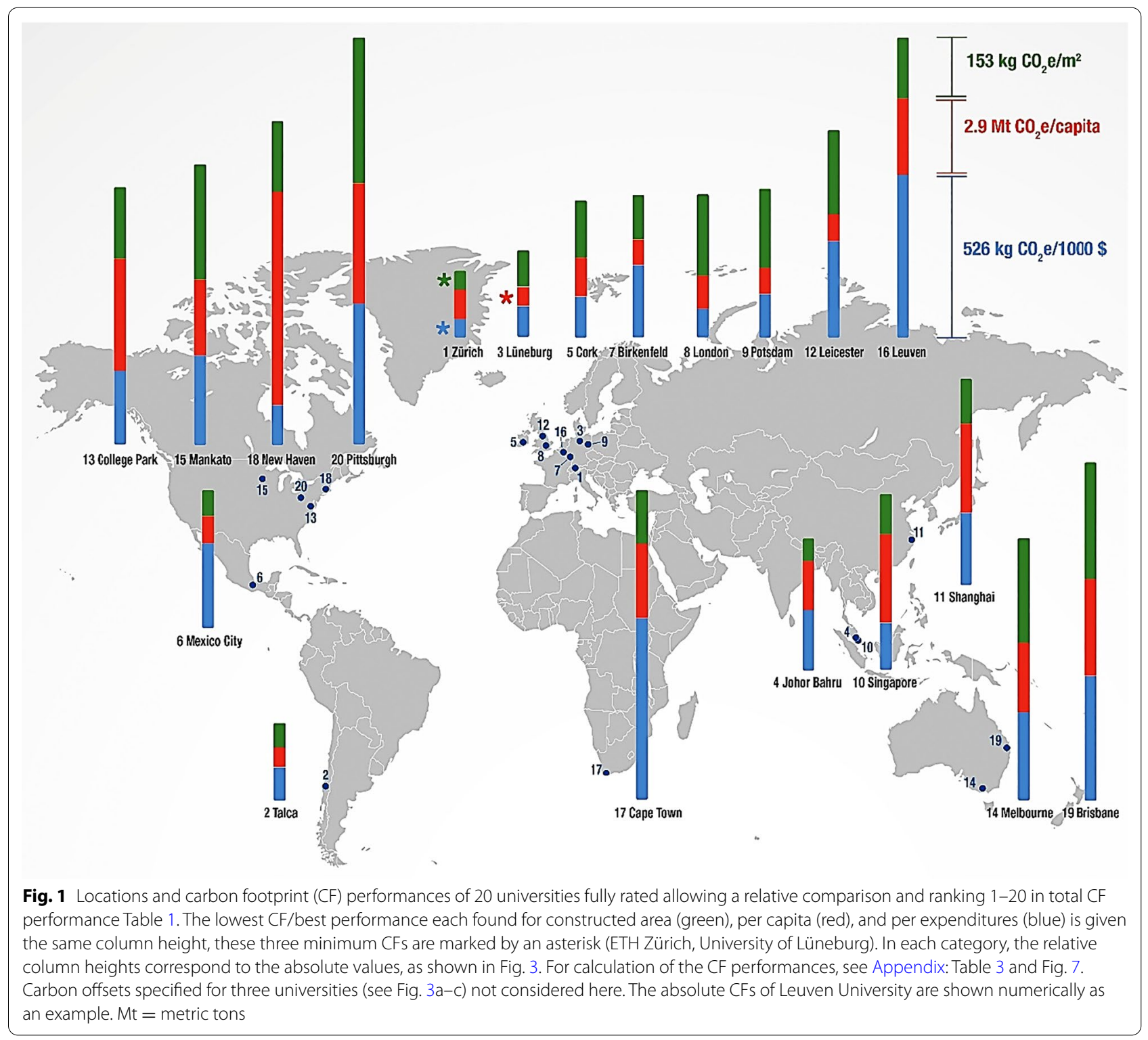


University of Cape Town, and Yale University) shifting energy production impacts to Scope 1. Many universities today have photovoltaic (PV) installations, such as the Nanyang Technological University (NTU), Umwelt-Campus Birkenfeld, and the Leuphana University Lüneburg, respectively, which is relocating a part of their energy production impact from Scope 2 to Scope 1. Additionally, if the university operates its own car vehicle fleet, these impacts as well belong to Scope 1 . When using external vehicles on business trips; however, it is a Scope 3 impact. As a whole, it is challenging to compare university carbon impacts based on separation into Scopes 1-3 due to the GHG Protocol Corporate Accounting and Reporting Standard. Therefore, we base our comparison on impact categories instead of Scopes.

In this way, we were able to quantify the CFs of 20 universities worldwide more precisely than known before with three independent CF parameters, identifying some of the most carbon-efficient universities. Such objective and detailed comparison had not yet been conducted in the literature, and is the main contribution of this study. Kennedy and Sgouridis [12] suggested a more rigorous emission classification scheme which would more precisely allow defining (zero) emission targets, however, the structure of publicly available data does not allow the application of such schemes here.

The rest of the paper is organized as follows. In "Materials, methods and purpose" section, we first describe the strategy of data collection, evaluation and completion. In "Results and discussion" section, we compile an overview of worldwide university CFs using three independent metrics, next, we analyse inter-correlations between the metrics, and compare the significance of university CFs relative to the national CFs. Finally, we present options to approach net zero carbon emissions, and offer concluding remarks.

\section{Materials, methods, and purpose}

This survey started by analysing scientific papers published on university CFs worldwide. It turned out; however, that the scientific literature contains only a limited number of studies with often very different methodology in data collection and interpretation. As a result, a valid quantitative description of the status quo in university carbon footprinting is difficult to conduct. Accordingly, for this study, next to scientific sources, university reports were additionally consulted. Many universities, however, only published (small) parts of their impacts or just total amounts, so we had to limit ourselves to the most detailed reports. From those universities periodically publishing $\mathrm{CO}_{2}$ emissions, the most recent reports were analysed, in addition to the most recent reports providing detailed data about the university operations, such as budget information. Finally, this analysis yielded CF data of 22 universities worldwide, 18 of them reporting a detailed impact record (Fig. 2). It was impossible to collect data from just 1 year: Some universities report yearly, some publish every few years, while others only published their $\mathrm{CO}_{2}$ emissions once. The period of collected data is between 2008 and 2018 (see Table 1). While it is easy to identify more US and British universities publishing carbon emission data, this is not the case for universities in other regions of the world. We scanned the literature and internet resources until we were able to cover all continents.

We directly adopted $\mathrm{CO}_{2} \mathrm{e}$ emissions as they were reported by the universities. In contrast, we calculated all $\mathrm{CO}_{2} \mathrm{e}$ emissions from Umwelt-Campus Birkenfeld (Germany) based on the collected energy and material consumption data. Also, we quantified the mobility impacts of Umwelt-Campus Birkenfeld from commuting and travelling data. Following the same method, we quantified mobility data for 5 universities which did not report them (see Table 1). For the University of Potsdam, we quantified the $\mathrm{CO}_{2}$ e emissions by freshwater consumption (extrapolated from the wastewater impact). The $\mathrm{CO}_{2} \mathrm{e}$ factors for all consumptions and activities considered this way are reported in the Appendix.

It is an essential focus of this study to estimate the performance of universities worldwide in reducing their CF. In this context, the question arose which impacts comprehensively describe university performance in $\mathrm{CO}_{2}$ emission limitation/reduction, and, respectively, which essential impacts are to be considered. Even after filtering those universities with satisfying documentation, it turned out that often different impacts had been measured (Fig. 2). Several scientific studies deliver statistics on which impacts were quantified how often (e.g., [20, 21]), however, without a critical quantitative assessment. This study intends to investigate the main contributing impacts towards a university's CF, and, on the other hand, to identify impacts that may be dropped as such impacts are negligible or are similar across all universities.

The 18 universities reporting a detailed carbon impact record quantified 28 single impact categories that we decided to consider (others were removed, see Table 1 and below). For better clarity, we condensed the 28 impact categories into 16 impacts areas (Fig. 2), from which we can infer those emission impacts mostly relevant for a university's CF. After collecting, sorting, revising, and complementing the impacts, in the next step, we relate the $\mathrm{CO}_{2} \mathrm{e}$ emissions to the size of a university. In this way, we obtained size-normalized CFs, allowing us to compare universities independent from their size.

University CFs have been evaluated in the scientific literature so far in two ways: in terms of per constructed/ 


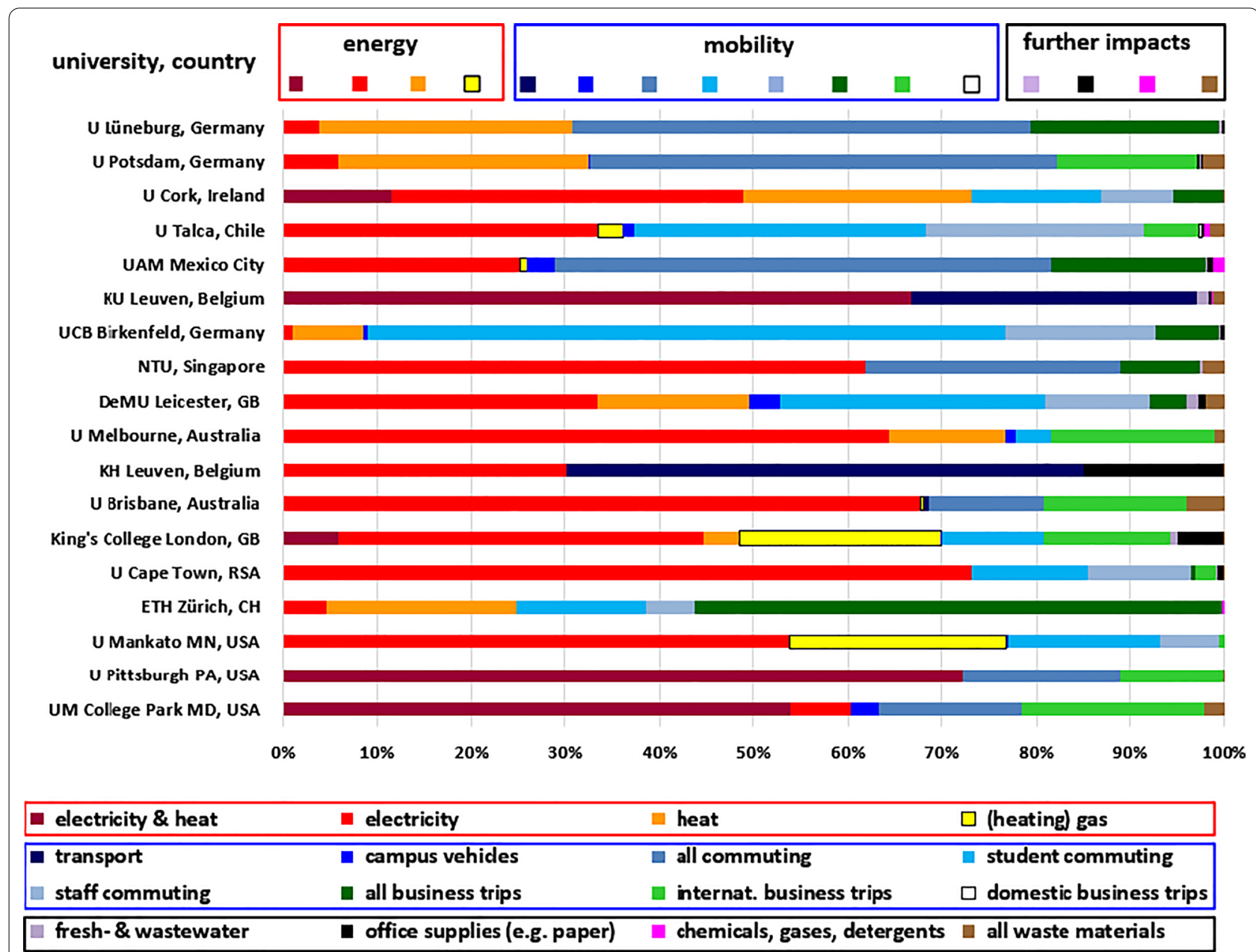

Fig. 2 Distribution pattern of partial carbon emission impacts at 18 universities worldwide: energy consumption (red/orange/yellow), mobility impacts (blue/green/white), and other impacts. University (U) specifications and full names are listed in Table 1, abbreviations listed in Fig. 3 caption. Note: electricity and heat may be listed twice in case the university received it from internal plus external sources. Results in numerical form are available in Appendix: Table 2

built area and per capita. We apply the term "constructed enclosure area" (or, simplified, "floor") in this publication as an umbrella term to cover the different terms and definitions of the building floor area found in the respective countries (see explanations below Table 1). King's College seems to be the first university additionally relating its $\mathrm{CF}$ to an economic factor, the university income, reporting a decrease from 140 to $30 \mathrm{~kg} \mathrm{CO}_{2} \mathrm{e} / 1,000$ British Pounds between 2005 and 2019 [22]. We follow this idea, but suggest to modify the quantification method. We believe that university expenditures have a stronger impact on the $\mathrm{CF}$ than university income, since most expenditures directly impact the CF, while parts of the income may be saved. A linear relationship between household carbon footprints and total household expenditure has been reported in [23]. Consequently, we collected data on university expenditures of 20 universities in this study. After subtracting the respective salary payments, we related the resulting expenditures (the procurement related spending) to the respective amount of emitted $\mathrm{CO}_{2} \mathrm{e}$. We converted expenditures to US $\$$, consequently, we are able to apply purchasing power parity (PPP) and currency fluctuation correction with factors provided by [24], we refer to the Appendix for more details.

\section{Results and discussion Emission impacts to consider Energy impacts}

Undoubtedly, the biggest part of a university's carbon impact is the energy consumption in terms of electricity and heat production (red and yellow colours in Fig. 2). 


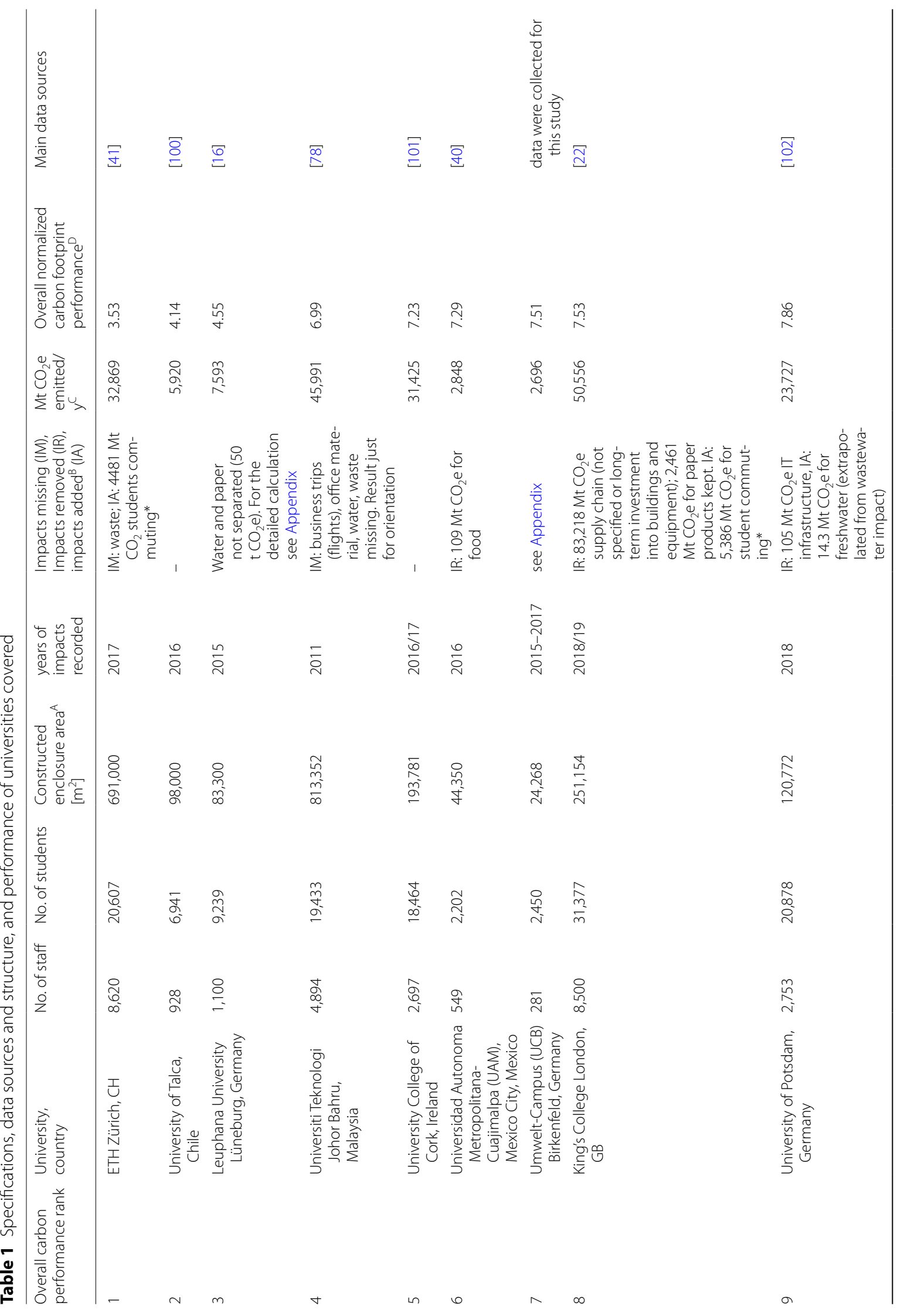




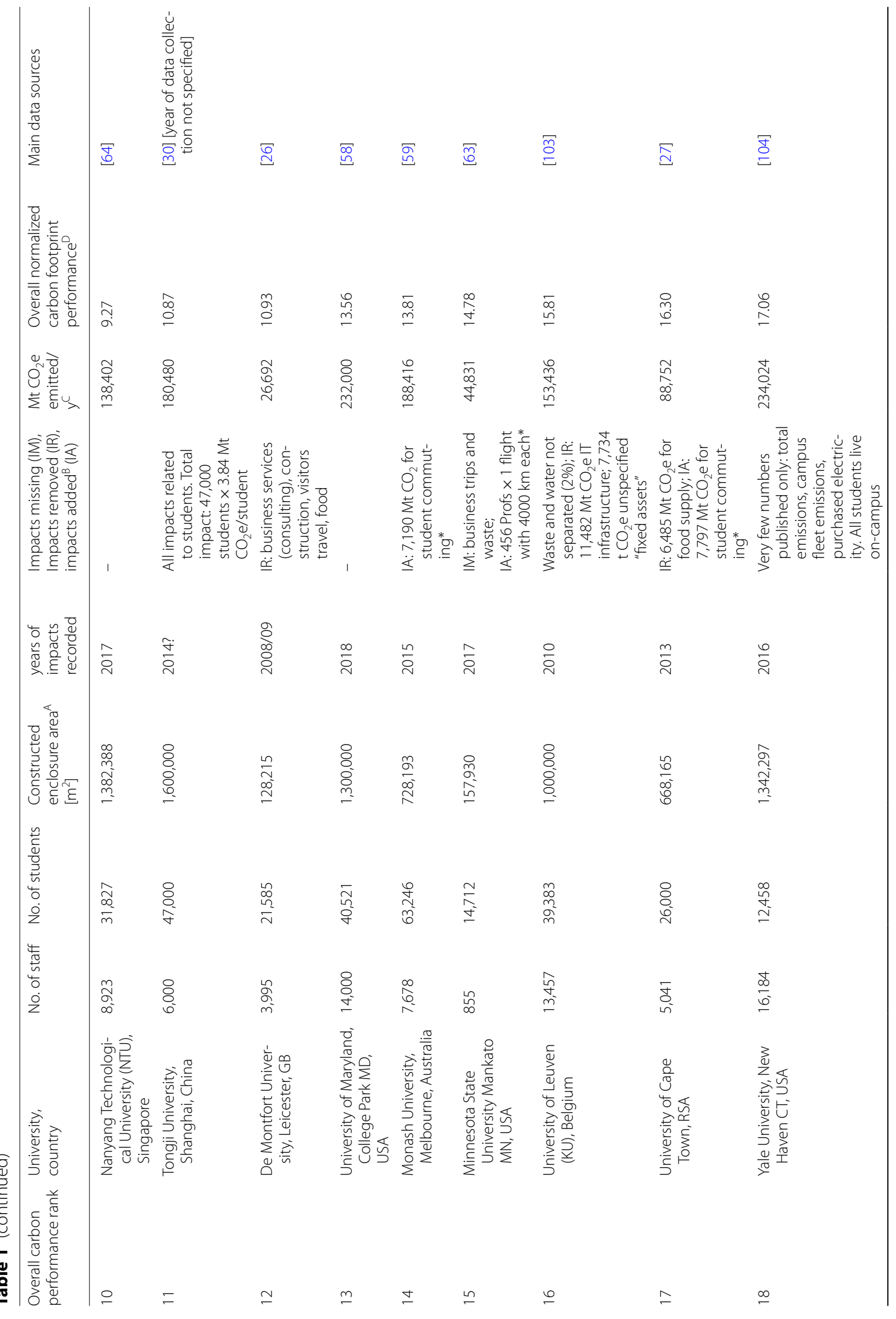




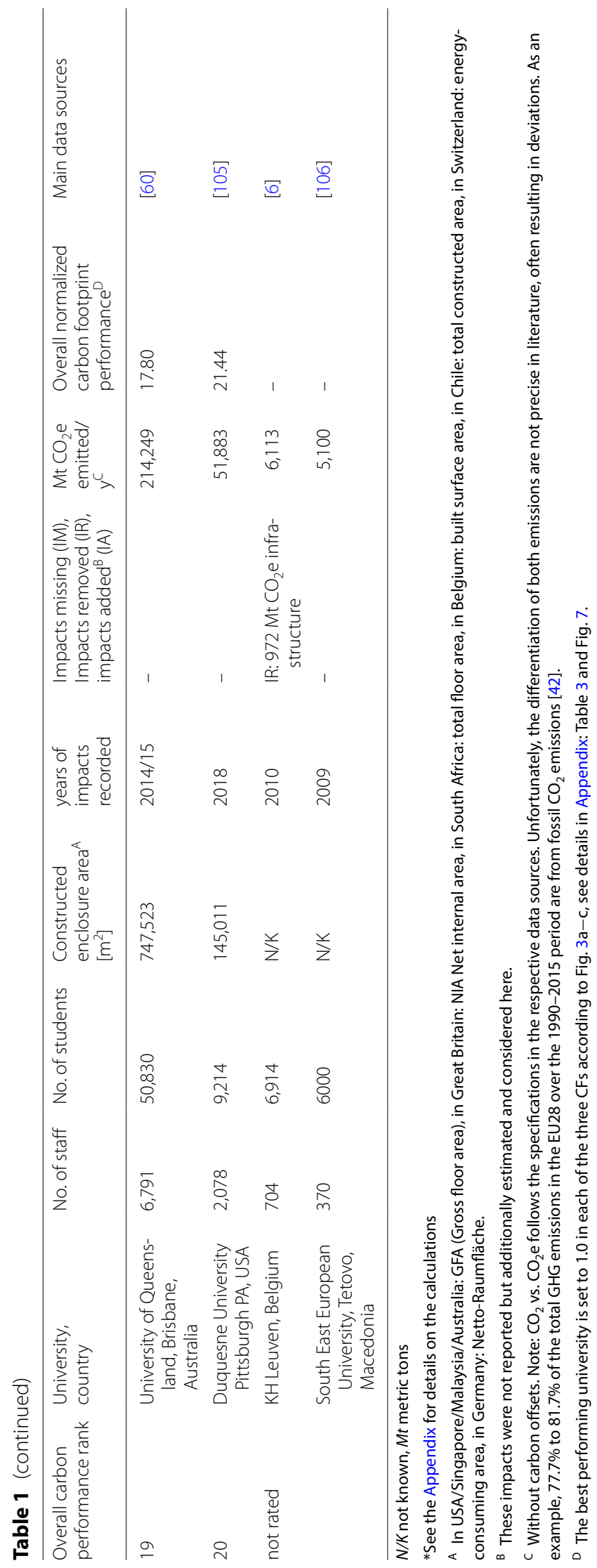


The percentages of energy consumption (the four related impacts taken together) ranges from 8.6\% (Umwelt-Campus Birkenfeld) to $76.8 \%$ (Minnesota State University Mankato), with an average of $52.1 \%$ (Fig. 2). UmweltCampus Birkenfeld has the lowest percentage of energy consumption in its overall $\mathrm{CO}_{2}$ emissions due to access to $100 \%$ renewable energy production. As an analogy, a university campus behaves similarly to the Life Cycle impact of an electric car, which is largely influenced by the availability of renewable electricity to charge the car in the use phase [25].

The fact that all universities report different groups of (energy-related) impact statistics prevents a more indepth analysis of the energy sector. Some differentiate energy sources and/or fuels; others only report summarized units. We do not know exactly the purpose of the energy sources, e.g., gas might be consumed for either heating, cooling, or even cooking. Ultimately, the university ends up with a total amount of $\mathrm{CO}_{2}$ emission computed by aggregating all energy consumptions. The university may consider how the mixture of energy sources can be optimized with respect to costs and emissions. The absolute $\mathrm{CO}_{2}$ emissions of every single impact can be calculated by multiplying the percentages reported in Appendix: Table 2 with the overall $\mathrm{CO}_{2}$ impact of the university listed in Table 1.

\section{Mobility}

The second set of impacts of relatively high importance is found in the area of mobility. Similar to the energy sector (see above), the reporting method of mobility-related impacts is very heterogenous among the universities considered in this study: two universities ( $\mathrm{KH}$ Leuven and KU Leuven, Belgium) only report the total emissions due to transport activities (see Fig. 2), while the other universities specified up to five different emission impacts due to mobility (see Appendix: Table 2).

The 18 universities that are providing the most detailed data (see Fig. 2) exhibited between 22.2\% (University of Melbourne) and 90.8\% (Umwelt-Campus Birkenfeld) mobility impacts. With an average of $45.3 \%$, mobility impacts are almost as important as the energy consumption for the overall $\mathrm{CO}_{2}$ emissions. Within mobility impacts, an average $27.7 \%$ of the overall university carbon impacts is due to commuting. Umwelt-Campus Birkenfeld with its remote campus location reaches the highest percentage with $83.8 \%$ commuting impact within the overall campus impact. As there are a lot of more students than staff (Table 1), student commuting alone makes up $67.8 \%$ of the overall campus $\mathrm{CF}$ at Umwelt-Campus Birkenfeld (Fig. 2). Given the relative importance of this impact, it is surprising that 4 of the 18 universities did not consider student commuting in $\mathrm{CF}$ quantification which is why we had to estimate and add it (for details, see the Appendix). Without these added impacts, it would not have been a fair CF inter-comparison within our set of universities. Only questionnaires among students and staff can derive detailed traffic mode statistics for a precise commuting impact estimation. When calculating the missing commuting impacts of four universities, we could partly resort to questionnaire results we found in the reports, alternatively, we analysed the specific traffic situation around a campus. The city of Zürich, as for example, is operating an excellent public transportation system and there are almost not parking spots available near ETH Zürich campus. Accordingly, we assumed $100 \%$ arrival by public transportation to ETH campus (for details, see Appendix). Universities in a very remote location (like Umwelt-Campus Birkenfeld) will always have to struggle with relatively high commuting impacts. In the future, politicians should take this location factor into account when deciding for certain locations to establish or enlarge a university. Those decisions are very important to impact the way towards a climate-neutral society.

Next to commuting, there is a lot of business transportation at and caused by university campus activities: The universities covered in this investigation quantified the impacts of campus vehicles (can be buses, business cars, or trucks), and domestic and international business trips (some report them condensed in one impact). Between 2.7\% (University of Cape Town) and 55.9\% (ETH Zürich) of the overall campus CF was caused by business transportation alone. Universities reporting detailed transportation impact data revealed a particularly high impact of international business travelling, caused by flying (up to $17.4 \%$ of the overall campus CF at Monash University, Melbourne). Accordingly, it is essential to consider the impact of air travelling, which is why we estimated and added this impact to that of Minnesota State University Mankato. Due to lack of data availability (number of professors), we could not estimate the air travelling impact at Tongji university (Shanghai) and Universiti Teknologi (Johor Bahru, see Table 1).

\section{Smaller impacts}

All further recorded impacts (freshwater and wastewater consumption, office supplies like paper, chemicals, gases, and detergent consumption, and waste disposal) result in just $0.14-14.9 \%$ (average: $2.6 \%$ ) of the overall university CF (Fig. 2 and Appendix: Table 2). We condensed several impact subcategories reported by the universities. Paper and offices supplies' consumption is the most important factor here, whereas the variation between the universities is substantial: Duquesne University (Pittsburgh) is reporting that $0.04 \%$ of its CF is caused by offices 
supplies, while KU Leuven publishes an amount of $14.8 \%$ for this contribution (see Fig. 2 and Appendix: Table 2). $0.1-1.3 \%$ (on average: $0.4 \%$ ) of the overall CFs was caused by freshwater consumed and wastewater generated. The consumption of chemicals, gases, and detergents adds another $0.01-1.3 \%$ (on average: $0.5 \%$ ) to the overall CFs of the universities. Most universities reported several impacts due to waste disposal, such as liquid, solid, laboratory and paper wastes, and composting impacts. Altogether, these result in $0.1-4 \%$ (on average: $2.7 \%$ ) of the overall university CFs (Fig. 2 and Appendix: Table 2).

\section{Impacts suggested to omit}

Apart from the aforementioned impacts that are essentially to be covered, there are other impacts in which we believe can be omitted to limit data complexity and ensure fair comparability. First, there is food, and its impact has been often reported (e.g., [26, 27]). However, humans need food independent to location or occupation. Although there are quite some local diet differences, we do not think that university CFs differ significantly in diet provision, particularly, in the light of the increasing fast food consumption among students, even in Asian countries (e.g., [28]). On the other hand, it can be the policy of a university to provide healthy and low CF food with little or no meat, or to integrate a responsible food consumption into the education for a sustainable development [29]. University canteens, however, are operated by external private companies at some campuses (like at Umwelt-Campus Birkenfeld and NTU Singapore), which result in limited data availability, and hence cause a lack in policy attempts to make food consumption more sustainable. The biggest argument against considering food consumption as part of university carbon footprinting is the fact that students and university personal consume only part of their daily meal in the university, typically only lunch.

One study quantified the mobility behavior in the students' private time (vacation travelling, [30]). Due to personal data protection policies, private mobility behavior can usually not be regularly recorded.

De Montfort University (Leicester) considered the impact of travels made by visitors to the university. Including such travels may jeopardize the standardized comparison between universities: large universities tend to organize more scientific conferences as they have more resources than small universities. Also, third parties may be (co-)organizing conferences held on university campuses, which brings up the question who is responsible for the impact. Therefore, we decided not to consider this impact in the present study.

Generally, as confirmed in this overview, university CF quantification today emphasizes the use phase impact of a university. Occasionally, we came across impact elements which lay outside the use phase, but are not clearly separated from it, for example, yearly investments in the buildings structure or IT architecture (as for example reported by the King's College and De Montfort University), partly called procurement impacts (e.g., [26]). Although infrastructure investments were often considered in university impact assessment [20], we believe use phase impacts and embodied impact assessment should be separated like it is common in Life Cycle Assessment (e.g., [31]). Embodied impacts of universities will be separately discussed in Part II of this project presentation (in preparation).

Acquisition of furnishings and IT architecture (servers, computers, and WLAN systems) cannot be clearly assigned to either the use phase or embodied impacts. On one hand, a university will purchase such infrastructure every year; on the other hand, it may be in use for many years. For the benefit of comparability, we have removed related procurement impacts. Additionally, almost all universities worldwide will be working with quite similar IT technology (central data servers and personal computers), almost every student today owns a notebook or tablet produced from only a few companies worldwide. Accordingly, we believe that the related impacts would not significantly distinguish universities from each other. This might change in the future when green(er) information technology becomes increasingly available for purchase [32, 33].

The life-cycle perspective, on the other hand, is considered in this study in the way that we based carbon impact calculations on input data which included supply chains, as far as possible (see Appendix). This refers to the impact calculations of our own universities (UCB Birkenfeld and NTU Singapore) but also to impacts of other universities which we supplemented (mostly commuting, see Table 1).

\section{Resulting university carbon footprints and their interpretation}

Universities physically consist of buildings, and buildings and construction together account for 39\% of energyrelated $\mathrm{CO}_{2}$ emissions in the world [34]. Accordingly, there are plenty of initiatives worldwide targeting to decrease the energy consumption of buildings, measured in terms of per $\mathrm{m}^{2}$ [34]. Square meters is accordingly an established functional unit in carbon footprinting of households [35], as it is as well the per-capita measurement of impacts from households [36].

The most detailed study available so far reported individual CFs for 42 buildings of Carleton university campus in Canada [37], ranging from 10 to $200 \mathrm{~kg} \mathrm{CO}_{2} \mathrm{e} / \mathrm{m}^{2}$, and

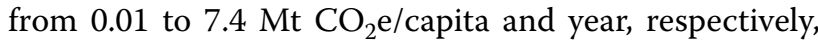


a U Pittsburgh PA, USA U Brisbane, Australia U Mankato MN, USA

U Melbourne, Australia

U Totovo, Macedonia

DeMU Leicester, GB

King's College London, GB

$U$ Potsdam, Germany

UM College Park MD, USA

Yale U New Haven CI, USA

KU Leuven, Belgien

U Cork, Ireland

$U$ Cape Town, RSA

U Tongji Shanghai, Chin

*UCB Birkenfeld, Germany

NTU, Singapore

*U Lüneburg, Germany

UAM Mexico City

U Talca, Chile

TU Johor Bohru, Moloysia
"ETH Zürich, CH

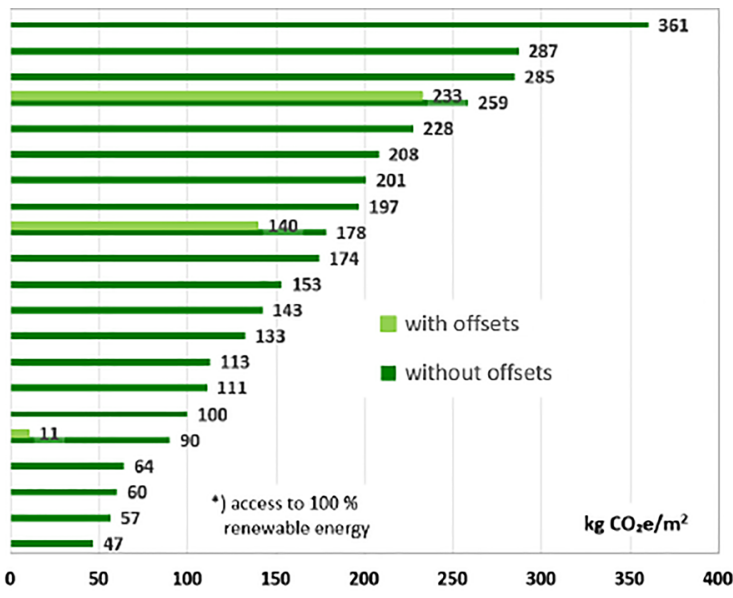

b

Yale U New Haven CT, USA U Pitts burgh PA, USA

UM College Park MD, USA

U Brisbane, Australia

U Tongji Shanghai, China

NTU, Singapore

KU Louven, Belgium

Mankato MN, USA

$U$ Cope Town, RSA

$U$ Melbourne, Australia

TU Johor Bahru, Malaysia

$$
U \text { Cork, Ireland }
$$

King's College London, $G B$

ETH Zürich, $\mathrm{CH}$

DeMU Leicester, GB

UAM Mexico City

Potsdam, Germany

UCB Birkenfeld, Germany

U Tetovo, Macedonia

KH Leuven, Belgium

U Talca, Chile

U Lüneburg, Germany 0.0 .09

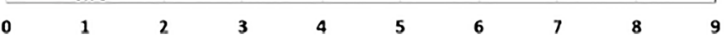

C

U Cape Town, RSA

KU Leuven, Belgium

U Pittsburgh PA, USA

U Brisbane, Australia

DeMU Leicester, GB

U Mankato MN, USA

U Melbourne, Australi

UAM Mexico City

UM College Park MD, USA

U Tongji Shanghai, China

UCB Birkenfeld, Germany

TU Johor Bahru, Malaysia

NTU, Singapore

U Potsdam, Germany

Yale U New Haven CT, USA

U Cork, Irelan

U Talca, Chile

U Lüneburg, Germany

King's College London, GB

ETH Zürich, $\mathrm{CH}$

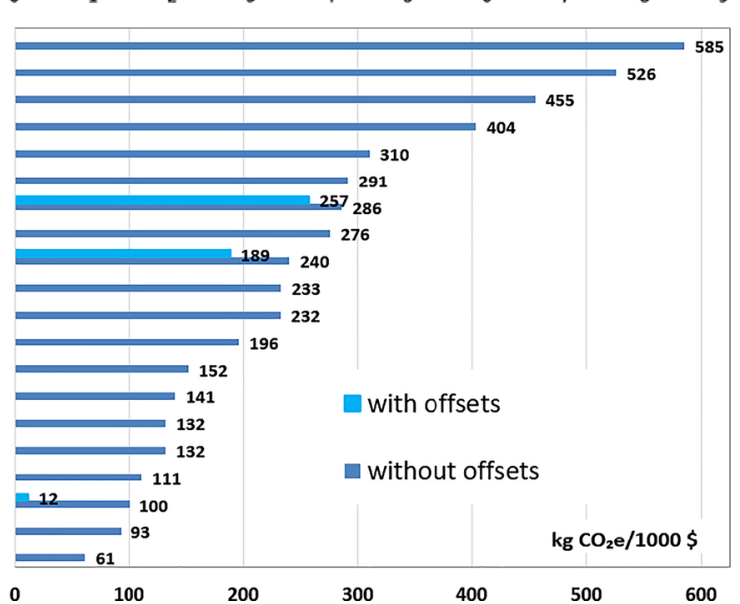

Fig. 3 Detailed university CF results per year for constructed area (a), per capita (b), and expenditures (c). Notes: 2 C is based on university expenditures without salaries and has been corrected for purchasing power parity (PPP) — for details, we refer to the Appendix: Fig. 6. Offsets: three of the universities covered are compensating $\mathrm{CO}_{2}$ emissions by purchasing carbon credits or producing a surplus of renewable energy. $\mathrm{Mt}=$ metric tons. $\mathrm{U}=$ University. Universities are named in the graphs with respect to the cities they are located. Some have deviating/completing names: UM College Park MD= University of Maryland. U Mankato MN= University of Minnesota. U Melbourne, Australia= Monash University. U Brisbane = University of Queensland. U Pittsburgh PA = Duquesne University. DeMU Leicester = De Montfort University. NTU = Nanyang Technological University. UCB = Umwelt-Campus Birkenfeld. UAM= Universidad Autonoma Metropolitana-Cuajimalpa. Tongji University Shanghai (3c) based on research budget only 
which is quite similar to the ranges which we observed in our international comparison (Fig. $3 \mathrm{a}+\mathrm{b}$ ). Based on current literature review, there is no study on any arearelated international university $\mathrm{CF}$ comparison $\left(\mathrm{kg} \mathrm{CO}_{2} \mathrm{e} /\right.$ $\mathrm{m}^{2}$ and year), and hence, this study should be the first one (see Fig. 3a).

The results of all three CF units span one order of magnitude (Fig. $3 \mathrm{a}-\mathrm{c}$ ). Relating the carbon impacts to $\mathrm{PPP}$-corrected university expenditures is smoothing the results considerably: As an example, University of Cape Town generates an outlier with $1,067 \mathrm{~kg} \mathrm{CO}_{2} \mathrm{e} / 1000$ \$ without PPP correction which is almost halved after PPP correction (Fig. 3c, also see Appendix: Fig. 6 for more details). We suggest to establish this economic CF factor as an additional unit expressing how efficient a university is decreasing its CF related to budget. Specifically, a budget might be invested to purchase carbon offsets (see below). This would quickly improve the CF of a university in terms of its $\mathrm{kg} \mathrm{CO}_{2} \mathrm{e} / 1000$ \$ record. Also, a university can generally decide to invest into carbon-efficient products and services (e.g., [38]), which can be more expensive, but would also reduce the $\mathrm{CF}$ in terms of the $\mathrm{kg} \mathrm{CO}_{2} \mathrm{e} / 1000 \$$ record.

Among the university CFs discussed in the literature, the CF per capita is the one most frequently reported. In a few cases, the per capita CF has been related to university students only (e.g., $[30,39])$ instead of to the entire university population (students plus staff). Relating the $\mathrm{CF}$ to students alone would reduce the functions of a university to teaching alone. We believe that university research is having the same relevance, and it is performed largely by the scientific university staff, only to a smaller part by students. The technical and administration staff is supporting both functions of a university. Concluding, we see decisive reasons to base the university $\mathrm{CF}$ on the entire university population (staff plus students).

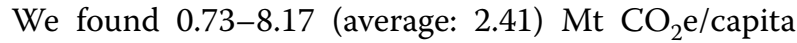
and year among 22 universities covered (see Fig. 3b). This order of magnitude has been confirmed by earlier studies: for example, the carbon emissions per staff and student amounted to around 1-3 $\mathrm{Mt} \mathrm{CO}_{2} /$ capita and year among 20 British HEIs, with an upward trend between 2005/06 and 2009/10 [21]. In a recent review, MendozaFlores et al. [40] reported 0.29-6.51 (average: 1.80) Mt $\mathrm{CO}_{2} /$ capita and year among 15 universities worldwide covering the years 2007-2017, however, that is without the corrections and amendments, we are applying in this study. Li et al. [30] published unusually high CF numbers in terms of $\mathrm{Mt} \mathrm{CO}_{2} \mathrm{e}$ /person and year, ranging from 3.84 (China) to 7-10 (Japan, Europe), arriving at $20 \mathrm{Mt} \mathrm{CO}_{2} \mathrm{e} /$ person and year in USA, which cannot be explained by the fact that they related the CF to students alone.
While the two CF parameters $\mathrm{kg} \mathrm{CO}_{2} \mathrm{e} / \mathrm{m}^{2}$ (Fig. 3a, mean: 2.36) and $\mathrm{kg} \mathrm{CO}_{2} \mathrm{e} / 1000$ \$ expenditures (Fig. 3c, mean: 248) both exhibit a linear distribution of results, the per capita parameter displays an agglomeration of 11 from 22 universities around $1 \mathrm{Mt} \mathrm{CO}_{2} \mathrm{e} /$ person and year (see Fig. 3b). This number today seems to indent a university working carbon efficiently. However, whether or not a university consumes green electricity has an enormous impact on this result which we are illustrating with the following example. NTU (Singapore) ends up with a $\mathrm{CF}$ of 3.4 $\mathrm{Mt} \mathrm{CO}_{2} \mathrm{e} /$ person and year (Fig. 3b), based on an electricity consumed with a CF of $0.5 \mathrm{~kg} \mathrm{CO}_{2} \mathrm{e} / \mathrm{kWh}$. In case NTU would have access to the same green electricity that the ETH Zürich is consuming $\left(0.013 \mathrm{~kg} \mathrm{CO}_{2} \mathrm{e} /\right.$ $\mathrm{kWh}$, [41]), NTU's CF per capita would decrease from 3.4 to $1.35 \mathrm{Mt} \mathrm{CO}_{2} \mathrm{e}$ /person and year, As a result, it would belong to the group of universities with the lowest CF in this investigation. However, there is no such green electricity in sufficient quantity available in Singapore. In such a situation, buying carbon offsets might be the option to decrease the university's CF (see below).

Finally, we assign an overall score in carbon performance to each of the 20 best documented universities. The carbon footprint of the best performer in each of the three categories is set to 1.0 , and then, the three category records are summarized for the respective university. The best possible score (lower scores are better) in this way is 3.0; ETH Zürich reaches a 3.53 as this university performs best in two of the three impacts and is No 9 in the per capita CF (see Fig. 3). Table 1 reports the results of this overall carbon performance score (3.53-21.44) establishing a ranking of the 20 universities. This overall carbon performance score is visualized as well in Fig. 1. Carbon offsetting measures, undertaken by three universities, were not considered at this point, but are discussed below.

\section{Global distribution of university CF performances}

Appendix: Fig. 7 graphically depicts the overall scores in carbon performance. It is headed by a group of three: ETH Zürich (Switzerland), University of Talca (Chile), and Leuphana University of Lüneburg (Germany). Seven more universities belong to the top 10 performers: TU Johor Bahru (Malaysia), University of Cork (Irland), Universidad Autonoma Metropolitana-Cuajimalpa (UAM) in Mexico City, Umwelt-Campus Birkenfeld (Germany), King's College London (Great Britain), University of Potsdam (Germany), and Nanyang Technological University of Singapore. Interestingly, in this group of top 10 performers, there are small and big universities, spreading across eight countries and three continents (Europe, Asia, and South America). 
Figure 1 allows to search for a possible global correlation of CFs with, for instance, geographical latitude, based on the assumption that universities in warm countries would need to consume more electricity because of air-conditioning. There is no such trend visible (see Fig. 1). Universidad Autonoma Metropolitana-Cuajimalpa (UAM) in Mexico City, a university in a tropical climate, is having one of the best carbon performances (taking aside the CF related to expenditures, Fig. 1). Also Nanyang Technological University with its tropical location exhibits a relatively well carbon performance altogether (see Fig. 1).

Instead of with latitude, the per capita CFs correlate with the national CFs per capita (see below). Accordingly, universities in Australia and the USA exhibit the highest CFs (see Fig. 1). Europe, on the other hand, shows a striking number of low CF universities. One reason can be infrastructure: Other than in USA, in Europe, most buildings do not have air conditioning. Another reason is availability of green energy: in Germany and Switzerland, for example, institutions can opt for $100 \%$ green electricity.

\section{Correlation between the parameters investigated}

Intercorrelations were investigated each between the following parameters: $\mathrm{kg} \mathrm{CO}_{2} \mathrm{e} / 1000$ \$ expenditures, Mt $\mathrm{CO}_{2} \mathrm{e} /$ person, $\mathrm{kg} \mathrm{CO}_{2} \mathrm{e} / \mathrm{m}^{2}$, aggregated carbon performance, the number of staff plus students, and constructed enclosure area. From 12 correlation combinations investigated, there were just two exhibiting a correlation: the CF per capita and year related to the number of students and staff, and, respectively, the CF per capita and year related to the constructed enclosure area of the respective universities (see Fig. 4). The very low degree of intercorrelation, however, should not come as a surprise given the enormous heterogeneity in the distribution pattern of partial university carbon emissions (see Fig. 2).

Although these correlations are weak (see Fig. 4), universities seem to face difficulty in achieving a low per capita CF when growing in size. The problems of larger universities are most obvious when correlating the per capita CF with constructed enclosure areas (see Fig. 4b). We believe that this is due to the fact that larger universities are running infrastructure which is absent in smaller universities. For example, NTU (Singapore) is operating extended sports facilities including a swimming area, while such infrastructure is not available at the much smaller Umwelt-Campus Birkenfeld (Germany).

Correlation between university population and $\mathrm{Mt}$ $\mathrm{CO}_{2} \mathrm{e}$ /person spent (Fig. 4a) exhibited further peculiarities. First, we have excluded Yale University from the correlation, because Yale is generally enrolling, due to local university politics, a particularly low number of students. While the 20 universities investigated (excluding Yale)

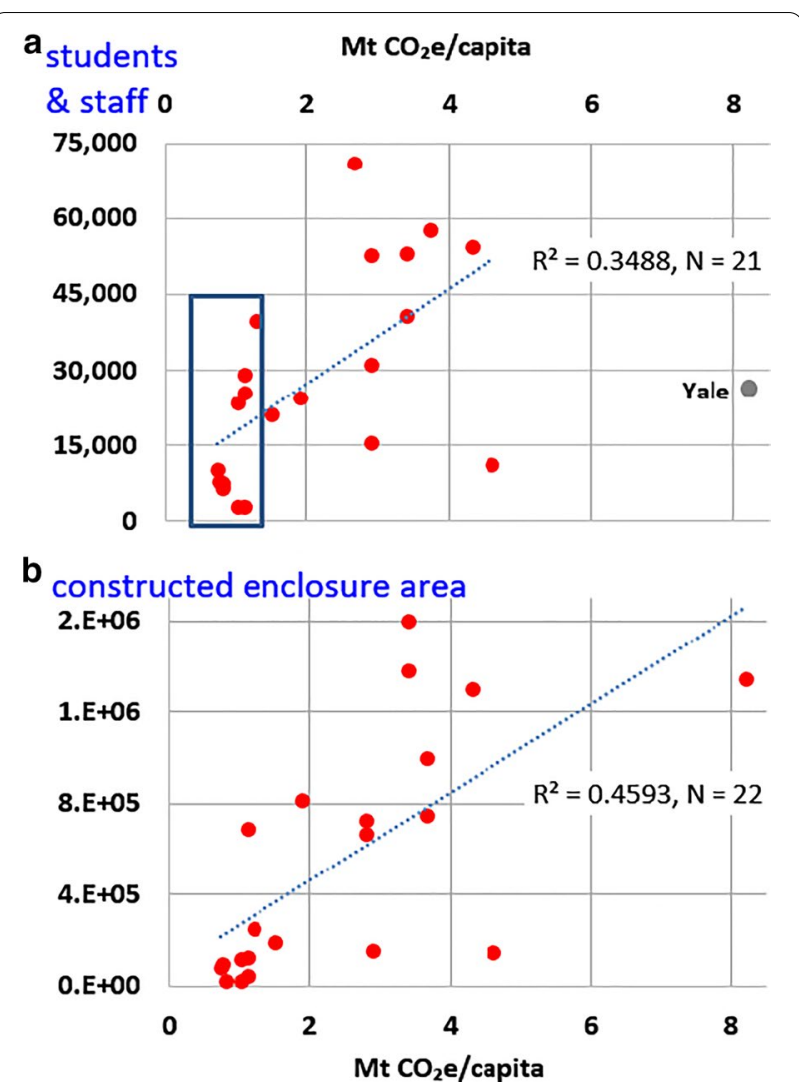

Fig. 4 University population (students plus staff, a) and constructed

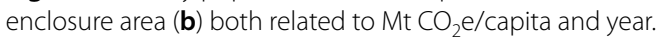
Coefficient of determination in graph $\mathrm{A}$ calculated excluding Yale University. The box (graph A) includes 10 universities reaching a per capita carbon footprint of lower than or close to $1.0 \mathrm{Mt} \mathrm{CO}_{2} \mathrm{e} /$ person and year. $\mathrm{Mt}=$ metric tons

have enrolled 2.4-17.2 (average: 6.2) times more students than staff employed, Yale enrolls just 0.8 times the number of students compared to number of staff available. Perhaps surprisingly, a high number of students-to-staff ratio does not automatically result in an advantageous capita-related CF: while University of Tetovo (Macedonia) with $16.2 \times$ more students than staff exhibits $0.9 \mathrm{Mt}$ $\mathrm{CO}_{2} \mathrm{e} /$ person, the Minnesota State University in Mankato with its $17.2 \times$ more students than staff ends up with a three times higher footprint $\left(2.9 \mathrm{Mt} \mathrm{CO}_{2} \mathrm{e} /\right.$ person, see Fig. 3b). Vice versa, De Montfort University Leicester (GB) with its students-to-staff ratio of only 5.4 is placed

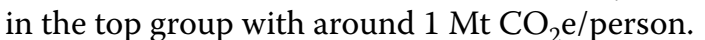

Astonishingly, however, the correlation between University population and $\mathrm{Mt} \mathrm{CO}_{2} \mathrm{e} /$ person spent (Fig. 4a) points to a group of universities maintaining a low per capita CF of up to or near $1.0 \mathrm{Mt} \mathrm{CO}_{2} \mathrm{e} /$ person, independent to the size of university population (see the box added in Fig. 4a). In other words, the ETH Zürich, Kings College London, University of Potsdam, and De Montfort 


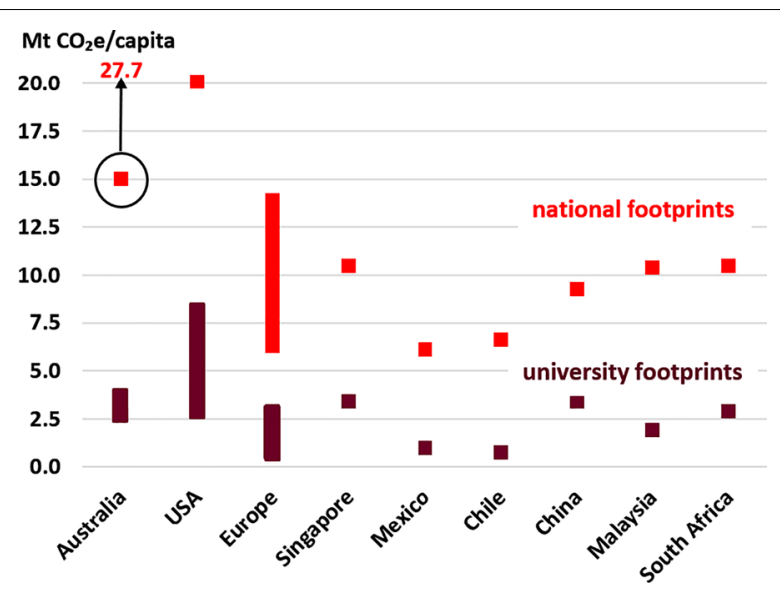

Fig. 5 University CFs per capita and year relative to national per capita footprints (the latter for 2015, taken from [42], areas shown for Australia, USA, and European countries with universities covered in this investigation ( $\mathrm{Mt}=$ metric tons)

University Leicester successfully reached around $1.0 \mathrm{Mt}$ $\mathrm{CO}_{2} \mathrm{e}$ /person and year although being relatively large with 20,000-30,000 students enrolled. Vice versa, the five universities in this comparison with the highest enrollment numbers $(39,383-47,000$ students, Tongji University Shanghai [China], the University of Maryland [USA], University of Leuven [Belgium], and the Universities of Brisbane and Melbourne [Australia]) all belong to the group of universities with the highest $\mathrm{CF}$ in terms of $\mathrm{Mt}$ $\mathrm{CO}_{2} \mathrm{e} /$ person.

\section{University CFs relative to national per capita CFs}

On average, university CFs per capita resulted in 23\% of the national per capita footprints (range: $12-37 \%$, Fig. 5). National per capita carbon emissions, as published by the EU commission, comprise emissions from fossil fuel use, industrial processes and product use [42]. These are consolidated in the Emissions Database for Global Atmospheric Research (EDGAR) providing pastand present-day anthropogenic emissions of greenhouse gases and air pollutants by country, including energy and manufacturing facilities, and road networks [43]. Accordingly, EDGAR data are in principle comparable to our determination of university CFs which are dominated by energy use and mobility. However, whereas EDGAR summarizes national emissions, we have based our university impact quantification on use phase plus supply chains. A part of the supply chains (e.g., vehicle production) may reach beyond the country in which the university is located.

When it comes to the carbon footprint of workplaces, economy sectors are compared with varying degree of energy intensity. The EU commission [44] emphasized that $70 \%$ of all workforce produces less than $12 \%$ of all $\mathrm{CO}_{2}$ emissions, including the sectors of construction, wholesale, retail trade, and other services. More specifically, Eurostat [45] reports that the sector of scientific research and development services in the EU28 spent just $12 \mathrm{~kg} \mathrm{CO}$ per inhabitant, and all education services spent $100 \mathrm{~kg} \mathrm{CO}_{2}$ per inhabitant, respectively, both domestic plus imported emissions for the year 2017. The overall GHG emission footprint in the European countries covered in our investigation, however, amounts to $10 \mathrm{Mt} \mathrm{CO}_{2} \mathrm{e} /$ capita in 2017 (calculated from [42]). Because we considered commuting and business travel within the universities' $\mathrm{CF}$, we might also compare the overall mobility impact of Europeans: $1.8 \mathrm{Mt} \mathrm{CO}_{2} \mathrm{e} /$ capita in 2017 [42], and $0.8 \mathrm{Mt} \mathrm{CO}_{2} \mathrm{e} /$ capita of it being related to travelling with cars and trains (calculated from [46]. The latter emissions plus the education and research/ development sector emissions amounts to $0.91 \mathrm{Mt} \mathrm{CO}_{2} \mathrm{e} /$ capita in 2017, equivalent to $9.1 \%$ of the overall per capita GHG emissions in Europe, and close to the 12\% CF per capita, we quantified for European universities relative to the national impacts (Fig. 5).

University per capita CFs correlate with the national CFs (Fig. 5), which is to be expected: while emissions from electricity production often dominate the national CFs [42], this is as well the case for emissions from electricity consumption of universities. Universities are connected to the national electricity grid, as long they do not separate themselves by operating their own power plants.

Europe exhibits a striking number of low CF universities (see Table 1), as the 10 European universities studied here have on average just $12 \%$ CF per capita compared to the national per capita CFs (as well averaged). On the other hand, this investigation lacks representativity and may be biased: we did not specifically search for carbonefficient universities, but for universities publishing sufficient data necessary for a full evaluation. However, universities with good documentation may be just the universities successful in carbon emission minimization, and therefore publishing their success. In other words, we would not have (any) data from those universities not interested or not engaged in CF optimization.

Given the relatively high magnitudes of per capita university footprints (see Fig. 5), saving energy/reducing CFs within universities would conversely decrease the respective national footprints: at German universities, for example, there are 2.9 million students enrolled [47]. Adding around $10 \%$ university staff results in 3.2 million people, equivalent to $3.85 \%$ of the national population [48]. There are nations with higher numbers: college enrollment alone makes up roughly $5.6 \%$ of the entire US population (based on data from [49]). Hence, transforming 
universities into carbon-efficient institutions should be handled as a high-priority national endeavour.

\section{Relating the CF to research orientation of universities}

It may be expected that research oriented universities might show higher carbon footprints than universities that are less research active, due to the more complex infrastructure and more staff members necessary to support research activities. However, this is not reflected in the results here: The university of Lüneburg as a research oriented HEI is among the leading institutions when it comes to its carbon footprints (Figs. 1, 3 and Table 1). Umwelt-Campus Birkenfeld, which may be regarded as less research oriented, even displays a slightly weaker carbon record (see Figs. 1, 3 and Table 1). Both represent relatively small campuses. The expectation that research activities increase the footprints is also not confirmed for big institutions. The nine universities in this study with the lowest CF (performance ranks 1-9, see Table 1) include five research oriented HEIs with between 18,464 and 31,377 students, among them the ETH Zürich and the King's College London as top research universities (Table 1), the latter two each operating a medical department with its very high infrastructure costs and impacts.

The critical factors for attaining a low carbon footprint on a university campus are as follows. It needs dedicated low-energy building technology and access to renewable energy (e.g., University of Lüneburg and Umwelt-Campus Birkenfeld, Germany), as well as continuous investments and resources necessary to optimize energy consumption and reduce emissions. Not by chance, the ETH Zürich published its first $\mathrm{CO}_{2}$-emission report already in 2004 which included a historical analysis back to 1990 [50], while the King's College London is recording $\mathrm{CO}_{2}$ emissions since 2005 [51], and is running a program to stimulate carbon-efficient behavior by distinguishing sustainability champions [52].

\section{Approaching zero emissions: carbon offsetting}

Reducing $\mathrm{CO}_{2}$ emissions by a small fraction is no longer sufficient to reach a long-term stable climate globally. Many institutions and technologies will have to try to reach zero emissions. The European Commission has accepted this challenge and is aiming for climate neutrality by the year 2050 [53]. The term "zero emissions", however, needs to be defined: carbon neutrality, for example, would require (net) zero $\mathrm{CO}_{2}$ emission in the global economy, and technically, it is a hypothetical concept today: there is not a single IPCC concept achieving it [54]. In contrast, "net zero carbon emissions can be achieved by balancing any remaining $\mathrm{CO}_{2}$ emissions by $\mathrm{CO}_{2}$ removals of exactly the same amount" (Rogelj et al. 2015, note: net zero GHG emissions should be targeted instead of just $\mathrm{CO}_{2}$ ). Monash University (Melbourne) seems to embrace this concept in its "Net zero initiative" [38]. It intends to reach zero carbon emissions in 2030 by implementing zero energy buildings, establishing renewable electricity plants and halving energy consumption. However, a net zero concept today can only work with an excess of green energy production or when combined with another compensation mechanism.

The much smaller Leuphana University Lüneburg is demonstrating this: by maximum employment of modern building technology and highly sophisticated green energy management (e.g., a high-temperature aquifer thermal energy storage), the university produces a surplus of energy and can thus almost completely offset its own GHG emissions (recalculated after [16], see Appendix).

Leuphana University Lüneburg even claims to have several 1,000 Mt of negative $\mathrm{CO}_{2} \mathrm{e}$ emissions per year [16]. However, when recalculating the balances more conservatively (not assuming hydropower electricity to be spent, not neglecting commuting and business trips, and quantifying the offset $\mathrm{CO}_{2} \mathrm{e}$ earnings due to feeding in the surplus renewable electricity into the net more realistically with respect to the average German carbon footprint, for more details, see Appendix), then the university can certainly compensate its emissions. We found Leuphana university having the third lowest aggregated carbon performance (see Table 1), without considering the offsets. Because of its very low overall $\mathrm{CF}$, even the $100 \%$ renewable energy consumption of this campus makes up to $30.7 \%$ of its overall CF. However, when considering the energy offsets earned by Leuphana University Lüneburg (after recalculation, see Appendix), then the CFs reach very low numbers, almost approaching zero Fig. $3 \mathrm{a}-\mathrm{c}$ ). Leuphana University Lüneburg thus can be treated as the only zero (carbon) emission university in this investigation.

Consuming 100\% renewable electricity alone, however, does not qualify universities to become zero emission entity today, although this misunderstanding has been noticed in the statements of two universities in this investigation [18, 38]. It goes back to the definition of zero carbon buildings having zero net $\mathrm{CO}_{2}$ emissions from energy use [12]. Also energy producers in Germany actually mark their green electricity production as emitting $0.0 \mathrm{~g} \mathrm{CO}_{2} / \mathrm{kWh}$, this way ignoring upstream emissions (e.g., [55]). In contrast, even renewable electricity production has a carbon footprint today (e.g., PV electricity production comes with around $50-80 \mathrm{gCO}_{2} \mathrm{e} / \mathrm{kWh}$, according to [56]). This impact needs to be compensated. The above reduced definition of "zero emission" also ignores impacts caused by people working in buildings.

Carbon emission compensation ("offsetting") can be implemented with the Clean Development Mechanism (CDM) allowing the use of compensation mechanisms through flexible application of the Kyoto Protocol [57]. 
Other than Udas et al. [9] state, CDM may open a standard way to become carbon-neutral. Several universities are already on this way: University of Maryland, also planning to reach zero carbon emissions, reported an offset of around 50,000 $\mathrm{Mt} \mathrm{CO}_{2} \mathrm{e}$ due to purchasing carbon credits [58]. Monash University (Melbourne) reported an 18,883 $\mathrm{Mt} \mathrm{CO}_{2} \mathrm{e}$ offset as follows: "Car fleet fuel consumption was offset with permanent biodiverse native forests planted by a greenhouse friendly approved abatement provider" [59]. Further universities covered in this investigation have announced to start a carbon offset program (e.g., the University of Queensland, see [60]).

How expensive is the compensation of $\mathrm{CO}_{2} \mathrm{e}$ emissions? An international pollutant valuation review resulted in monetarized impacts of 27-164 (average: 77) \$/Mt of $\mathrm{CO}_{2}$ [61]. The purchase of voluntary certificates for $\mathrm{CO}_{2}$ compensation is more reasonable with $5-80$ (average of five commercial programs: 27.3) $€ / \mathrm{Mt}$ of $\mathrm{CO}_{2}$ [62]. Given the 2,696 $\mathrm{Mt} \mathrm{CO}_{2}$ e emitted by the Umwelt-Campus Birkenfeld in 2017, it would need an investment of 73,601 $€$ to fully compensate its emissions and reach net zero, equivalent to just $0.8 \%$ of expenditure (without salaries) made in 2017. To compensate its $32,869 \mathrm{Mt} \mathrm{CO}_{2}$ e emission, the ETH Zürich would have to buy carbon certificates for $897,324 €$, equivalent to only $0.17 \%$ of its expenditures (without salaries) made in 2017. The question arises why this is not done yet at universities.

\section{Limitations and strengths of this investigation}

- While emissions from energy consumption and business travels can be exactly measured, the questionnaires on which quantification of commuting impacts is based deliver relatively weak estimations: only a fraction of students and staff out of the whole population is participating in such exercise, and the student generations are interchanging quickly which can continuously modify their habits. However, so far, there has been no alternative available for quantification of commuting emissions.

- University CFs from single (budget) years are subjected to meteorological changes causing a bias to the data. Universities seeking to manage their CF should, therefore, quantify the meteorological influence. Schwartzkopf and Urban [63] provided weather-normalized data for Minnesota State University (Mankato), exhibiting an up to $15 \%$ of meteorological influence on heating energy consumption, for example.

- Next to the influence of weather conditions, the emissions of specific years might be biased by university growth and opening of new buildings. Metha et al. [64] have developed a method quantifying these influences.

- This investigation provides a status quo in worldwide university CFs based on 1-year university data in the period of 2008-2018. Thus, we hereby only see snapshots in the long-term carbon performance of these universities. Instead, a long-term longitudinal study would be more appropriate, but data are often lacking for such endeavour.

- Almost all universities documenting CFs set themselves goals for CF reduction. As universities started at different years in managing and decreasing their CFs, this should not cause an additional bias.

- Missing impacts had to be estimated for a couple of universities resulting in lower data precision. However, even a not so precise estimation of impacts like commuting improves the accuracy of the university CF compared to when omitting the respective impact. Consequently, this enabled a more harmonized inter-university CF comparison.

\section{Conclusions}

Although already initiated in 1993, the process of ecoimpact reduction seems to be still in its infancy among universities worldwide. Several hundred universities have started to document climate relevant emissions, developing plans to minimize them. An even smaller number of universities are publishing their emission records. However, emissions of important sources such as commuting are often not included. It also turned out that published emission budgets need critical reviewing, not only because they may be incomplete, but also because budgets may be based on unrealistic assumptions and uncommon definitions.

Universities can actually reach zero carbon emissions, proven by Leuphana University in Germany, which achieves this goal through maximum use of modern technology and on-site surplus renewable energy production. However, maximum use of technology means a particular high upstream carbon impact due to the materials incorporated. This can implicate extended pay-back times and change the carbon performance, an effect which has not yet been quantified for universities.

Besides modern technology, low or even zero carbon emissions can be achieved by purchasing carbon certificates. We believe that both pathways will need to be combined.

Moreover, we realized that almost every university in the world, independent of its climate zone, its focus and profile, can reach very low carbon footprints, based on the political will, necessary investments granted and the 
creativity needed from their researchers. Smaller and universities in urban areas can go achieve low CFs more easily because of less infrastructure and mobility impacts. The availability of a green energy supply, however, is generally a crucial factor. Based on the expected worldwide transition towards increasing renewable energy production in the coming decades [65], carbon footprints of energy provision might need a new way of quantification $[66,67]$.

This is in no way a criticism on certain universities for having a higher CF than others. All universities considered in this overview are to be commended in the way that they quantify and publish (parts of) their CF, hence are thus among the leading universities worldwide in this regard. Obviously, the majority of worldwide universities do not publish any or any useful impact data. As universities are innovation drivers in science and technology, and thus are willing to accept their responsibility to support the transformation towards a sustainable world, this should change and become a much broader movement.

\section{Appendix}

Impacts were quantified in most cases from process data obtained from the German/international GEMIS/ProBas databases, which generally consider upstream effects [68, 69].

\section{Umwelt-Campus Birkenfeld (UCB), University of Applied Sciences Trier (Germany) UCB: Energy}

The campus is provided with electricity and heat by a neighbouring combined heat and power plant (CHP) burning waste wood. This plant is owned by the regional electricity company, which also provides $100 \%$ renewable electricity to the campus. We quantified the electricity impacts with a matching impact specified by GEMIS [70]: $18 \mathrm{~g} \mathrm{CO}_{2} \mathrm{e} / \mathrm{kWh}$. The campus purchased electricity with an impact of $22.94 \mathrm{Mt} \mathrm{CO}_{2} \mathrm{e}$ this way.

PV electricity is additionally provided by campus-own CdTe-moduls having an impact of $0.024 \mathrm{~kg} \mathrm{CO}_{2} / \mathrm{kWh}$. (impact factor provided by [71]). Additionally there is electricity produced by monocrystalline $\mathrm{PV}$, calculated with $0.061 \mathrm{~kg} \mathrm{CO} 2 \mathrm{e} / \mathrm{kWh}$ [70]. This way the campus indirectly emitted $1.3 \mathrm{MtCO}_{2} \mathrm{e}$.

The district heating system loaded by the above CHP plant provides heat with an impact factor of $0.065 \mathrm{~kg}$ $\mathrm{CO}_{2} \mathrm{e} / \mathrm{kWh}$ [70] resulting in an impact of $206.5 \mathrm{Mt} \mathrm{CO}_{2} \mathrm{e}$. Heat is as well produced by a campus-own solar collector (0.025 kg CO $2 \mathrm{e} / \mathrm{kWh}$, [70]) adding 0.35 $\mathrm{Mt} \mathrm{CO}_{2} \mathrm{e}$.

\section{UCB: Water, wastes and office material}

Freshwater consumption is considered with a conversion factor of $0.381 \mathrm{~kg} \mathrm{CO} / \mathrm{m}^{3}$ [72] causing $3.27 \mathrm{Mt} \mathrm{CO}_{2}$. A campus-own rainwater collection unit added freshwater with an impact of $0.33 \mathrm{~kg} \mathrm{CO}_{2} / \mathrm{m}^{3}$ [73], another $0.51 \mathrm{Mt}$ $\mathrm{CO}_{2}$ were brought about this way. Wastewater disposal was considered based on $0.254 \mathrm{~kg} \mathrm{CO} / \mathrm{m}^{3}$ [72] adding $3.8 \mathrm{Mt} \mathrm{CO}_{2}$ to the $\mathrm{CF}$ of the campus. All solid wastes were quantified with a conversion factor of $0.0218 \mathrm{~kg}$ $\mathrm{CO}_{2} / \mathrm{kg}$, just composting material with $0.006 \mathrm{~kg} \mathrm{CO}_{2} / \mathrm{kg}$ [74], resulting in an impact of $1.41 \mathrm{Mt} \mathrm{CO}_{2}$.

Office material was converted to $\mathrm{CO}_{2}$ impacts as follows: envelopes and paper with a factor of $1.28 \mathrm{~kg} \mathrm{CO}_{2} /$ $\mathrm{kg}$ [72], toner with a factor of $4.8 \mathrm{~kg} \mathrm{CO}_{2} / \mathrm{kg}$ [75], respectively. Taken together, both resulted in an impact of 9.7 $\mathrm{Mt} \mathrm{CO}_{2}$.

\section{UCB: Mobility impact assessment}

Input data used for mobility impact modelling were taken from different sources. Carbon footprint for international flight $\mathrm{km}$ were taken from the German federal "process based basic data for environmental management systems", resulting in $153 \mathrm{~g} \mathrm{CO}_{2} / \mathrm{km}$ including supply chain [76].

CF when using personal cars were quantified during full LCA modelling resulting in 268,5 $\mathrm{g} \mathrm{CO}_{2} \mathrm{e} / \mathrm{km}$ [25]. CFs of public buses and trains have been researched in the literature resulting in averages of $120,9 \mathrm{~g}$ and $68,9 \mathrm{~g}$ $\mathrm{CO}_{2} \mathrm{e} / \mathrm{PKM}$, respectively [25]. Business trips caused an impact of $177.1 \mathrm{Mt} \mathrm{CO}_{2} \mathrm{e}$, internal business cars added another 10.7 Mt of $\mathrm{CO}_{2}$ at Umwelt-Campus Birkenfeld.

\section{Commuting}

Detailed quantification of commuting impacts is based on questionnaires. First of all, it is essential to estimate how many days/weeks a year students visit the university. This was quantified as being 36 weeks/year on average at Umwelt-Campus Birkenfeld, which was applied as well on other universities.

A questionnaire at Umwelt-Campus Birkenfeld in 2015 delivered the following numbers:

- $16,06 \%$ of the students live on campus. They drive home once a week by car (180 km per weekend).

- The rest of the students commute 3 days a week from home to university driving $66.66 \mathrm{~km} /$ day (43.6\% by train, $6.5 \%$ by bus, $33.9 \%$ by car), due to the questionnaire.

- There are lectures on 30 weeks in a year; additionally the students need to arrive for 20 written exams per year, resulting in 110 days of commuting to the cam- 
pus per year $(\rightarrow 7,326 \mathrm{~km}$ of commuting/student $\mathrm{x}$ year with the above mix of transport).

- Among the staff, 36\% commute by train, $3.9 \%$ by bus, $60.1 \%$ by car. Driving impacts were calculated based on the same distances applied for the students. 184 working days were calculated per year.

Student commute results in an impact of 1,826.8 Mt $\mathrm{CO}_{2} \mathrm{e}$, while the commuting impact of the staff amounted to $431.5 \mathrm{Mt} \mathrm{CO}_{2} \mathrm{e}$ at Umwelt-Campus Birkenfeld.

Commuting of students for foreign universities were calculated considering the number of places available for students to live on campus.

\section{ETH Zürich (Switzerland)}

Only recently that ETH Zürich has opened around 900 student rooms. Before this, there were no student dorms so far at ETH campus. Accordingly, most students $(19,707)$ have to commute daily for which we assume only half of the distance $(30 \mathrm{~km})$ per day compared to Umwelt-Campus Birkenfeld (UCB), because UCB is a rural site which requires longer distances for staff and students to travel, while e.g. the ETH Zürich is located in a metropolitan area.

Based on an excellent public transportation network available in the Zürich area (mostly train and tram), most students will travel using such transportation $(\rightarrow 68,9 \mathrm{~g}$ $\mathrm{CO}_{2} \mathrm{e} / \mathrm{PKM}$, see [25]). $110 \times 30 \times 68.9 \mathrm{~g} \mathrm{CO}_{2} / \mathrm{km} \times 19.707$ $\rightarrow 4,481 \mathrm{t} \mathrm{CO}_{2} \mathrm{e}$. This number exhibits that the $1,714 \mathrm{t}$ $\mathrm{CO}_{2}$ mentioned as spent for commuting, but without specification in detail, obviously means staff commuting [41].

\section{University of Cape Town (South Africa)}

UCT offers 6000 places in student dorms [77], hence the remaining 20,000 students need to commute. As $44 \%$ (8800) use their cars [27], student commuting CF was calculated by: $8,800 \times 110 \times 30 \times 268.5 \mathrm{~g} / \mathrm{km} \rightarrow 7,797 \mathrm{Mt}$
$\mathrm{CO}_{2}$ e. $38 \%$ commute via a shuttle service (mini bus): 20 , $000 \times 0.38 \times 110 \times 30 \times 120.9$ g CO$_{2} \mathrm{e} / \mathrm{km} \rightarrow 3,235$ t. Students commuting together: $11,032 \mathrm{Mt} \mathrm{CO}_{2} \mathrm{e}$.

\section{King's College London (Great Britain)}

[22] reported that $75.5 \%$ of the students commute with public transport, most of all by trains. Accordingly the commuting carbon impact was quantified as (comparably to the above universities in metropolitan areas): 110 days $\times 30 \mathrm{~km} \times(31.377 \times 0,755) \times 68.9 \mathrm{~g} / \mathrm{CO}_{2} \mathrm{e} \mathrm{PKM}$ $\rightarrow 5,386 \mathrm{Mt} \mathrm{CO}_{2} \mathrm{e}$.

\section{Monash University, Melbourne (Australia)}

The number of places in student dorms was not available in the internet, however, it was mentioned that there are many of such dorms in a distance of 10-65 km off campus(es). Therefore an average distance of $30 \mathrm{~km}$ a days was assumed for half of the students, travelled by train/tram: $\rightarrow 31,623 \times 110$ days $\times 30 \mathrm{~km} \times 68.9 \mathrm{~kg} \mathrm{CO} /$ $\mathrm{km} \rightarrow 7,190 \mathrm{CO}_{2}$ for student commuting.

\section{Universiti Teknologi Malaysia, Johor Bahru (Malaysia)}

It was not possible to figure out the number of professors as the data is not available online. Accordingly we could not estimate the business flight activity. Commuting impacts, however, have been included [78].

\section{Leuphana University Lüneburg (Germany)}

Based on [16] the consolidated CF of the university is composed of its electricity production (296 Mt $\left.\mathrm{CO}_{2} \mathrm{e}\right)$, heat production (2,036 $\left.\mathrm{Mt} \mathrm{CO}_{2} \mathrm{e}\right)$, freshwater and paper consumption (50 Mt $\mathrm{CO}_{2} \mathrm{e}$ ), commuting impacts (3,694 Mt $\left.\mathrm{CO}_{2} \mathrm{e}\right)$, business travelling $\left(1517 \mathrm{Mt} \mathrm{CO}_{2} \mathrm{e}\right)$, resulting in 7,593 Mt in total.

Calculation of offsets: Due to [16] the aquifer thermal energy storage installation results in additional savings of $2,424 \mathrm{t} \mathrm{CO}_{2} \mathrm{e} / \mathrm{y}$ which obviously corresponds with the excess thermal energy delivered to the neighbourhood. 


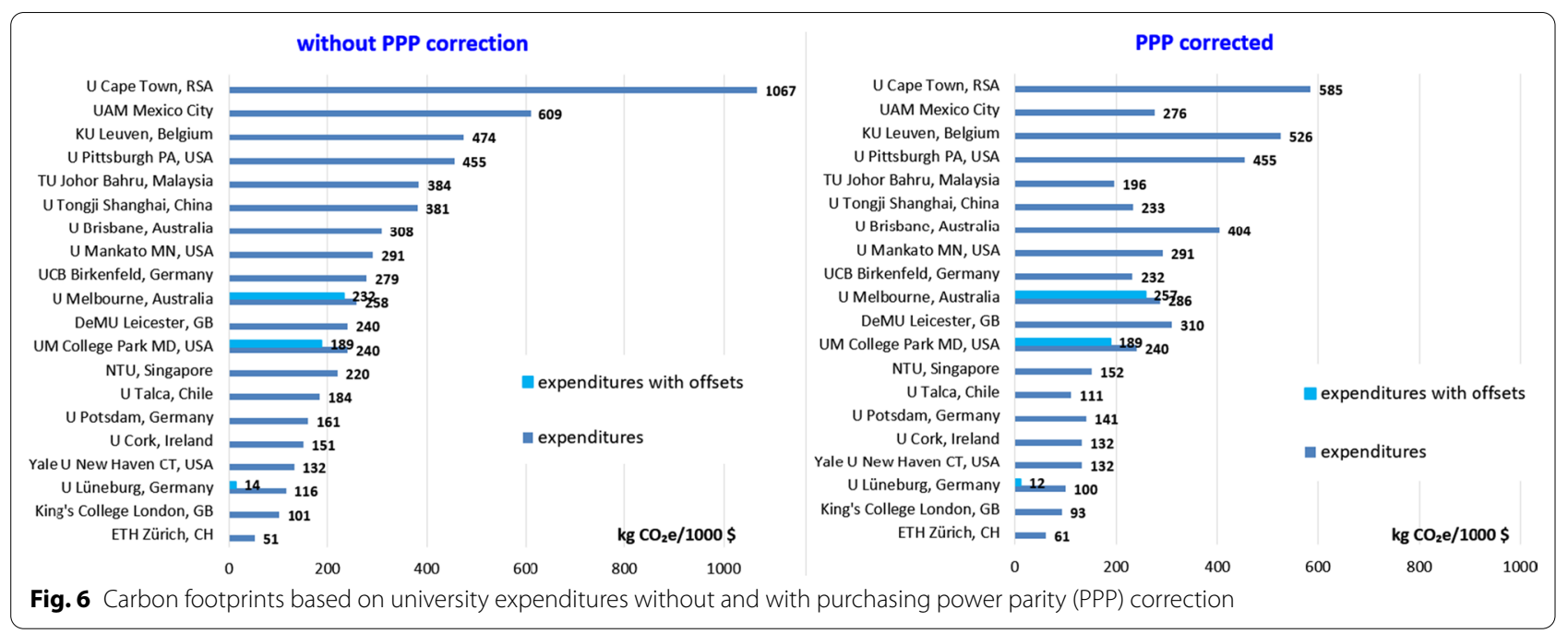

Additionally the university feeds in excess electricity into the network. [16] quantified the production impact based on hydropower $\left(5 \mathrm{~g} \mathrm{CO}_{2} \mathrm{e} / \mathrm{kWh}\right)$. We believe this should more realistically be based on the PV electricity production available $\left(80 \mathrm{~g} \mathrm{CO}_{2} \mathrm{e} / \mathrm{kWh}\right)$. [16] quantified the outside electricity CF saved based on electricity generation by coal fired power plants (821-921 $\left.\mathrm{g} \mathrm{CO}_{2} \mathrm{e} / \mathrm{kWh}\right)$, we quantify it based on the German electricity production impact specified by the German federal environmental agency [79] for the year 2015, which is $575 \mathrm{~g} \mathrm{CO}_{2} \mathrm{e} / \mathrm{kWh}$. Based on $8.65 \mathrm{GWh}$ surplus electricity production of the university [16], this results in an electricity offset of 4,282 $\mathrm{Mt} \mathrm{CO}_{2} \mathrm{e}$. Together with the surplus in heat production this results in an offset of 6,706 $\mathrm{Mt} \mathrm{CO}_{2} \mathrm{e}$ which has been confronted to the 7,593 Mt of $\mathrm{CO}_{2} \mathrm{e}$ emissions.

\section{Currency conversion and expenditure related CF quantification (PPP correction)}

University expenditures were taken from financial university reports [80-96].
The expenditures of the Umwelt-Campus Birkenfeld (UCB) and Universidad Autononma Metropolitana (UAM) in Mexico-City were provided by the university administrations.

Currency conversion factors were applied relative to the individual year of study. Singapore \$ were converted to US \$ according to [97], Malayan Ringgit were converted to US \$ according to [98]. All other currencies were converted to US $\$$ according to [99]. Dividing the carbon emissions $\left(\mathrm{Mt} \mathrm{CO}_{2} \mathrm{e}\right.$ emitted/y, Table 1) of the respective universities by the university expenditures in US \$ resulted in the CFs displayed in Appendix: Fig. 6 (left: without, right: with PPP correction), as well as in the CFs displayed in Fig. 3c. For PPP correction, university expenditures were corrected before division applying the factors provided by [24], specific to the respective year.

\section{Numerated partial carbon impacts of universities covered (supplementing Fig. 2)}

See Table 2. 
Helmets et al. Environ Sci Eur $\quad$ (2021) 33:30

Page 20 of 25

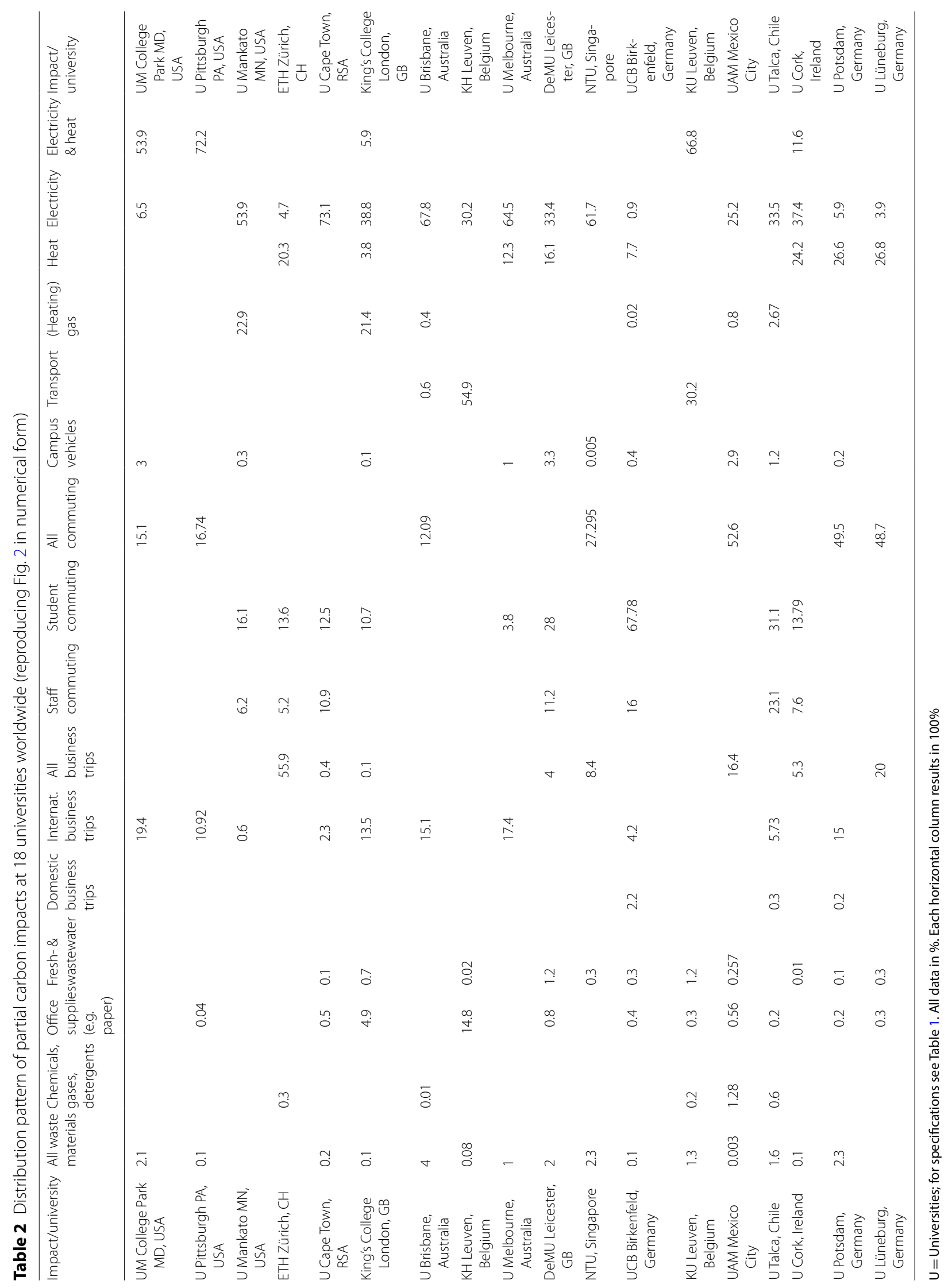




\section{Normalized carbon footprint (CF) performances}

\section{See Table 3 and Fig. 7.}

Table 3 Normalized carbon footprint (CF) performances. The lowest yearly CF each found for constructed area, per capita, and per expenditures (see Fig. $3 \mathrm{a}-\mathrm{c}$ ) is set to 1.0

\begin{tabular}{|c|c|c|c|c|c|}
\hline University & $\begin{array}{l}\text { A } \\
\mathrm{CF} \text { performance }[\mathrm{kg} \\
\left.\mathrm{CO}_{2} \mathrm{e} / \mathrm{m}^{2}\right] \\
\text { normalized to } 1.0 \text { for } \\
\text { the best performer }\end{array}$ & $\begin{array}{l}\mathrm{B} \\
\mathrm{CF} \text { performance } \\
{\left[\mathrm{Mt} \mathrm{CO}_{2} \mathrm{e} / \text { capita }\right]} \\
\text { normalized to } 1.0 \text { for the } \\
\text { best performer }\end{array}$ & $\begin{array}{l}\mathrm{C} \\
\mathrm{CF} \text { performance } \\
{[\mathrm{kg} \mathrm{CO} 2 \mathrm{e} / 1000 \$] \text { normalized }} \\
\text { to } 1.0 \text { for the best performer }\end{array}$ & $\begin{array}{l}\text { Overall normalized } \\
\text { CF performance } \\
(A+B+C)\end{array}$ & $\begin{array}{l}\text { overall carbon } \\
\text { performance } \\
\text { rank }\end{array}$ \\
\hline ETH Zürich, CH & 1.00 & 1.53 & 1.00 & 3.53 & 1 \\
\hline U Talca, Chile & 1.29 & 1.03 & 1.82 & 4.14 & 2 \\
\hline U Lüneburg, Germany & 1.92 & 1.00 & 1.63 & 4.55 & 3 \\
\hline TU Johor Bahru, Malaysia & 1.20 & 2.59 & 3.20 & 6.99 & 4 \\
\hline U Cork, Ireland & 3.03 & 2.04 & 2.16 & 7.23 & 5 \\
\hline UAM Mexico City & 1.37 & 1.42 & 4.50 & 7.29 & 6 \\
\hline UCB Birkenfeld, Germany & 2.36 & 1.36 & 3.79 & 7.51 & 7 \\
\hline King's College London, GB & 4.28 & 1.74 & 1.51 & 7.53 & 8 \\
\hline U Potsdam, Germany & 4.19 & 1.37 & 2.30 & 7.86 & 9 \\
\hline NTU, Singapore & 2.13 & 4.66 & 2.48 & 9.27 & 10 \\
\hline U Tongji Shanghai, China & 2.40 & 4.67 & 3.80 & 10.87 & 11 \\
\hline DeMU Leicester, GB & 4.43 & 1.44 & 5.06 & 10.93 & 12 \\
\hline UM College Park MD, USA & 3.80 & 5.84 & 3.92 & 13.56 & 13 \\
\hline U Melbourne, Australia & 5.50 & 3.64 & 4.67 & 13.81 & 14 \\
\hline U Mankato MN, USA & 6.06 & 3.97 & 4.75 & 14.78 & 15 \\
\hline KU Leuven, Belgium & 3.26 & 3.97 & 8.58 & 15.81 & 16 \\
\hline U Cape Town, RSA & 2.83 & 3.92 & 9.55 & 16.30 & 17 \\
\hline Yale U New Haven CT, USA & 3.71 & 11.19 & 2.16 & 17.06 & 18 \\
\hline U Brisbane, Australia & 6.11 & 5.10 & 6.59 & 17.80 & 19 \\
\hline U Pittsburgh PA, USA & 7.67 & 6.34 & 7.43 & 21.44 & 20 \\
\hline
\end{tabular}

The CFs reported for all universities (see Fig. 3) are related to the best performer in each category (without offsets). The overall performance is summarized from $A-C$ also shown in Table 1, and results in an overall performance rank. The best possible score of a university would be $\mathrm{a} 3.0(A+B+C)$. These data are plotted in Appendix: Fig. 7 below. $\mathrm{Mt}=$ metric tons 


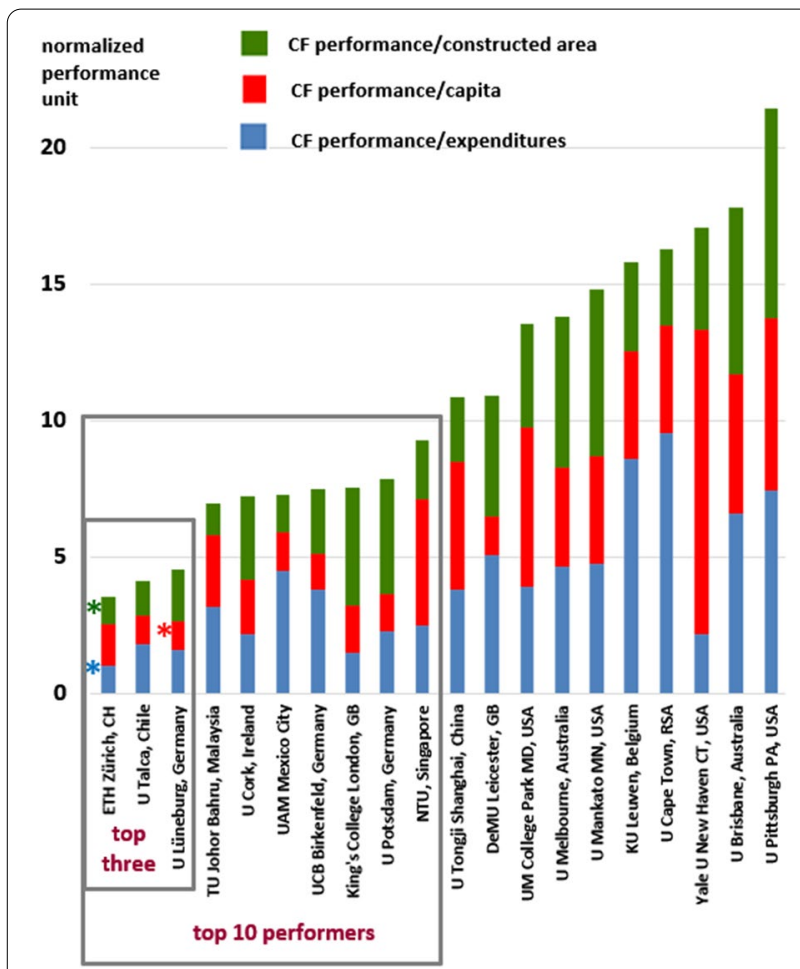

Fig. 7 Normalized carbon footprint performances. The plots display the data of Appendix: Table 3. The best performer in the categories A-C is set to 1.0 (marked by an asterisk). Without the offsets specified in Fig. 3a-c for three universities. The columns shown here are displayed on the world map in Fig. 1. CF $=$ Carbon footprint. $U=$ University. Universities are named with respect to the cities they are located. Some have deviating/completing names: UM College Park MD = University of Maryland. U Mankato $\mathrm{MN}=$ University of Minnesota. $U$ Melbourne, Australia = Monash University. $\cup$ Brisbane $=$ University of Queensland. U Pittsburgh $\mathrm{PA}=$ Duquesne University. DeMU Leicester = De Montfort University. $\mathrm{NTU}=$ Nanyang Technological University. $\mathrm{UCB}=$ Umwelt-Campus Birkenfeld. UAM = Universidad Autonoma Metropolitana-Cuajimalpa. Tongji University Shanghai: CF performance/expenditures based on research budget only

\section{Abbreviations}

Mt: Metric tons; CF(s): Carbon footprint(s); HEl(s): Higher education institution(s); NTU: Nanyang Technological University; UCB: Umwelt-Campus Birkenfeld; GHG: Greenhouse gases; kWh: Kilowatt hour; GWh: Gigawatt hour; $\mathrm{CO}_{2} \mathrm{e}: \mathrm{CO}_{2}$-equivalent emissions quantifying a global climate change impact (here: carbon impact).

\section{Acknowledgements}

We cordially thank Frank Gemeinhardt for Fig. 1 preparation, Karsten Swarat for translation from Malayan, Adela Irmene Ortiz Lopez and Marcia Vasquez Sandoval for providing additional data of their universities, Kira Cloos for data digging, and Andreas Schaffer for his support. Viola Helmers kindly commented on this manuscript and located PPP conversion factors. This manuscript benefitted very much from improvements kindly suggested by three reviewers. Sincere thanks to Christoph Frick (Umwelt-Campus Company $\mathrm{GmbH}$ ) and to Andreas Doll for providing comprehensive UCB buildings consumption data. E.H. would like to thank Associate Vice president Prof. Subodh
Mhaisalkar for supporting a research stay at the Nanyang Technological University in Singapore.

Dedicated to Prof. Dr. habil. Michael Schlaak - a great motivator in university sustainability research.

\section{Authors' contributions}

EH conceived the original idea, collected and analysed the data, and wrote and revised the manuscript. CCC and JD corrected and completed the manuscript. All authors read and approved the final manuscript.

\section{Funding}

Open Access funding enabled and organized by Projekt DEAL. The project received funding from Nanyang Technological University Singapore.

\section{Availability of data and materials}

The datasets supporting the research are included in the Appendix.

\section{Ethics approval and consent to participate}

Not applicable.

\section{Consent for publication}

Not applicable.

\section{Competing interests}

The authors declare that they have no competing interests.

\section{Author details}

${ }^{1}$ Dep. of Environ. Planning and Technology, University of Applied Sciences Trier, Umwelt-Campus, PO box 1380, 55761 Birkenfeld, Germany. ${ }^{2}$ Energy Research Institute (ERI@N), Nanyang Technological University, 50 Nanyang Avenue, Singapore 639798, Singapore. ${ }^{3}$ School of Electrical and Electronic Engineering, Nanyang Technological University, 50 Nanyang Avenue, Singapore 639798, Singapore.

Received: 23 October 2020 Accepted: 19 January 2021

Published online: 11 March 2021

\section{References}

1. Helmers E, Ilchmann F (2019) Sustainability subjects in university education-development of a comprehensive indicator system and quantitative analysis of degree programs at German Universities. Eur J Sustain Dev Res. 3(4), em0092, pp 1-17. https://doi.org/https://doi. org/10.29333/ejosdr/5771

2. UNECE 2020. How to incorporate the principles of sustainable development intothe Bologna Process. COPERNICUS-Guidelines for Sustainable Development in the European Higher Education Area. http://www. unece.org/fileadmin/DAM/env/esd/information/COPERNICUS\%20Gui delines.pdf. Accessed 4 Sept 2020

3. ISCN 2020. https://international-sustainable-campus-network.org/. Accessed 4 Sept 2020

4. Ramisio PJ, Costa Pinto LM, Gouveia N, Costa H, Arezes D (2019) Sustainability strategy in higher education institutions: lessons learned from a nine-year case study. J Clean Prod 222:300-309. https://doi. org/10.1016/j.jclepro.2019.02.257

5. Townsend J, Barrett J (2015) Exploring the applications of carbon footprinting towards sustainability at a UK university: reporting and decision making. J Clean Prod 107:164-176. https://doi.org/10.1016/j. jclepro.2013.11.004

6. Lambrechts W, Van Liedekerke L (2014) Using ecological footprint analysis in higher education: campus operations, policy development and educational purposes. Ecol Ind 45:402-406. https://doi.org/10.1016/j. ecolind.2014.04.043

7. Nunes LM, Catarino A, Teixeira MR, Cuesta EM (2013) Framework for the inter-comparison of ecological footprint of universities. Ecol Ind 32:276-284. https://doi.org/10.1016/j.ecolind.2013.04.007

8. Brodbeck AB, LeCompte JS, Meder AL, Ricker MC, Wedge M, Schurman H, Anderson CJ (2015) Evaluating a campus nitrogen budget for Auburn University, Alabama, USA. Urban Ecosyst 18:1187-1211. https:// doi.org/10.1007/s11252-015-0458-4 
9. Udas E, Wölk M, Wilmking M (2018) The "carbon-neutral university"—a study from Germany. Int J Sustain High Educ 19(1):130-145. https://doi, org/10.1108/IJSHE-05-2016-0089

10. University of Potsdam (2019) Klimaschutzkonzept der Universität Potsdam. Report, pp 99. https://www.uni-potsdam.de/fileadmin/proje cts/umweltportal/pdf/191209_ARC_U_Klimaschutzkonzept_der_Unive rstitat_final.pdf Accessed 3 Sept 2020

11. Stars (2020) The sustainability tracking, assessment \& rating system. Stars Participants \& Reports. https://reports.aashe.org/institutions/parti cipants-and-reports/?sort=rating. Accessed 3 Sept 2020

12. Kennedy S, Sgouridis S (2011) Rigorous classification and carbon accounting principles for low and Zero Carbon Cities. Energy Policy 39:5259-5268. https://doi.org/10.1016/j.enpol.2011.05.038

13. Green metric (2020) Green Metric World university rankings 2020. http://greenmetric.ui.ac.id/. Accessed 3 Sept 2020

14. THE (2020) The world university rankings. Top universities for climate action. https://www.timeshighereducation.com/student/best-universiti es/top-universities-climate-action. Accessed 3 Sept 2020.

15. Gov.Uk (2020) Guidance: Streamlined energy and carbon reporting for college corporations, Published 17 June 2020. https://www.gov.uk/ government/publications/college-corporation-financial-management -good-practice-guides/streamlined-energy-and-carbon-reporting-forcollege-corporations. Accessed 2 Sept 2020

16. Opel O, Strodel N, Werner KF, Geffken J, Tribel A, Ruck WKI (2017) Climate-neutral and sustainable campus Leuphana University of Lueneburg. Energy 141:2628-2639. https://doi.org/10.1016/j.energ y.2017.08.039

17. Leuphana (2020). Klimaneutrale Universität. https://www.leuphana. de/universitaet/entwicklung/nachhaltigkeit/klimaneutrale-universita et.html. Accessed 4 Sept 4, 2020

18. UCB (2020) Green-Campus-Concept. https://www.umwelt-campus.de/ en/campus/life-on-campus/green-campus-concept. Accessed 6 Sept 2020

19. WRI (2011) Corporate Value Chain (Scope 3) Accounting and Reporting Standard - Supplement to the GHG Protocol Corporate Accounting and Reporting Standard. Report, world resources institute. https://ghgpr otocol.org/sites/default/files/standards/Corporate-Value-Chain-Accou nting-Reporing-Standard_041613_2.pdf. Accessed 30 Sept 2020

20. Lo-lacono-Ferreira VG, Torregrosa-Lopez JI, Capuz-Rizo SF (2016) Use of Life Cycle Assessment methodology in the analysis of Ecological Footprint Assessment results to evaluate the environmental performance of universities. J Clean Prod 133:43-53. https://doi.org/10.1016/j.jclep ro.2016.05.046

21. Robinson O, Kemp S, Williams I (2015) Carbon management at universities: a reality check. J Clean Prod 106:109-118. https://doi.org/10.1016/j. jclepro.2014.06.095

22. King's (2020) King's College London Environmental Sustainability report. 17 pp. https://www.kcl.ac.uk/aboutkings/strategy/pdfs--resources/envir onmentalsustainabilityreport201819.pdf. Accessed 25 Sept 2019

23. Chitnis M, Sorrell S, Druckman A, Firth SK, Jackson T (2014) Who rebounds most? Estimating direct and indirect rebound effects for different UK socioeconomic groups. Ecol Econ 106:12-32. https://doi. org/10.1016/j.ecolecon.2014.07.003

24. World Bank Group (2020) DataBank—World Development Indicators. https://databank.worldbank.org/reports.aspx?source $=2 \&$ series=PA. NUS.PPP\&country=\#. Accessed 29 Dec 2020

25. Helmers E, Dietz J, Weiss M (2020) Sensitivity analysis in the life-cycle assessment of electric vs. combustion engine cars under approximate real-world conditions. Sustainability MDPI 12: 1241. https://www.mdpi. com/2071-1050/12/3/1241/pdf

26. Ozawa-Meida L, Brockway P, Letten K, Davies J, Fleming P (2013) Measuring carbon performance in a UK University through a consumptionbased carbon footprint: De Montfort University case study. J Clean Prod 56:185-198

27. Rippon S (2015) University of Cape Town Carbon Footprint Report 2014. 27 pp. https://www.uct.ac.za/sites/default/files/image_tool/image s/328/explore/sustainability/reports/UCT_Carbon_Footprint_Repor t_2014.pdf. Accessed 24 Sept 2020

28. Banik R, Naher S, Pervez S, Hossain MM (2020) Fast food consumption and obesity among urban college going adolescents in Bangladesh: a cross-sectional study. Obes Med 17:100161. https://doi.org/10.1016/j. obmed.2019.100161

29. Feijoo G, Moreira MT (2020) Fostering environmental awareness towards responsible food consumption and reduced food waste in chemical engineering students. Educ Chem Eng 33:27-35. https://doi. org/10.1016/j.ece.2020.07.003

30. Li X, Hongwei Tan H, Rackes A (2015) Carbon footprint analysis of student behavior for a sustainable university campus in China. J Clean Prod 106:97-108. https://doi.org/10.1016/j.jclepro.2014.11.084

31. Helmers E, Weiss M (2017) Advances and critical aspects in the life-cycle assessment of battery-electric cars (review). Energy Emiss Control Technol 5:1-18. https://doi.org/10.2147/EECT.S60408

32. Esfandyari A, Härter S, Javied T, Lean FJA (2015) Based overview on sustainability of printed circuit board production assembly. Procedia CIRP 26:305-310. https://doi.org/10.1016/j.procir.2014.07.059

33. Zaman B, Sedera D (2015) Green Information Technology as Administrative innovation organizational factors for successful implementation: literature review. In: Australasian conference on information systems 2015, Adelaide. https://arxiv.org/pdf/1606.03503. Accessed 29 Sept 2020

34. UN (2017) Towards a zero emission, efficient, and resilient buildings and construction sector - Global status report 2017. United Nations Environment Programme. https://www.worldgbc.org/sites/default/files /UNEP\%20188_GABC_en\%20\%28web\%29.pdf. Accessed 9 Jan 2021

35. Druckman A, Jackson T (2016) Chapter 9-Understanding households as drivers of carbon emissions. In: R Clift, A Druckman (eds) Taking stock of industrial ecology, Springer Open, pp 181-203. doi: https://doi. org/10.1007/978-3-319-20571-7_9

36. Goldstein B, Gounaridis D, Newell JP (2020) The carbon footprint of household energy use in the United States. Proc Natl Acad Sci 117(32):19122-19130. https://doi.org/10.1073/pnas.1922205117

37. Abdelaim A, O'Brien W, Shi Z (2015) Visualization of energy and water consumption and GHG emission: a case study of a Canadian University Campus. Energy Build 109:334-352. https://doi.org/10.1016/j.enbui ld.2015.09.058

38. Monash (2020) Monash net zero initiative. Brochure. https://www. monash.edu/_data/assets/pdf_file/0010/2042668/Monash-Net-ZeroBrochure.pdf. Accessed 4 Oct 2020

39. Letete TCM, Mungwe NW, Guma M, Marquard A (2011) Carbon footprint of the University of Cape Town. J Energy Southern Africa 22(2):2-12

40. Mendoza-Flores R, Quintero-Ramírez R, Ortiz I (2019) The carbon footprint of a public university campus in Mexico City. Carbon Management 10(5):501-511. https://doi.org/10.1080/17583004.2019.1642042

41. ETH (2018) ETH Zurich—Sustainability report 2017/18. 102 pp. https:// ethz.ch/content/dam/ethz/main/eth-zurich/nachhaltigkeit/Berichte/ Nachhaltigkeitsbericht/ETHzurich_Sustainability_Report_2017_2018_ web.pdf. Accessed 24 Sept 2020

42. Crippa M, Oreggioni G, Guizzardi D, Muntean M, Schaaf E, Lo Vullo E, Solazzo E, Monforti-Ferrario F, Olivier JGJ, Vignati E (2019) Fossil $\mathrm{CO}_{2}$ and GHG emissions of all world countries. 2019 JRC Science for policy report. https://op.europa.eu/en/publication-detail/-/publication/9d09c cd1-e0dd-11e9-9c4e-01aa75ed71a1/language-en. Accessed 20 Sept 2020

43. EU (2020) Emissions database for global atmospheric research. https:// data.jrc.ec.europa.eu/collection/edgar. Accessed 4 Feb 2020

44. EU (2019) Employment and Social Developments in Europe Sustainable growth for all: choices for the future of Social Europe. Annual Review 2019. https://ec.europa.eu/social/main.jsp?catld=738\&langl $\mathrm{d}=$ en\&publd=8219. Accessed 8 Jan 2021

45. Eurostat (2019) Energy, transport and environment statistics 2019 edition. https://ec.europa.eu/eurostat/documents/3217494/10165 279/KS-DK-19-001-EN-N.pdf/76651a29-b817-eed4-f9f2-92bf692e1e $\mathrm{d} 9 ? \mathrm{t}=1571144140000$. Accessed 8 Jan 2021

46. EEA (2021) Indicator assessment-Greenhouse gas emissions from transport in Europe. https://www.eea.europa.eu/data-and-maps/indic ators/transport-emissions-of-greenhouse-gases/transport-emissionsof-greenhouse-gases-12. Accessed 8 Jan 2021

47. Destatis (2019) Zahl der Studierenden erreicht im Wintersemester 2019/2020 neuen Höchststand. Press release No. 453, 27 November 2019, German Federal Office of Statistics, https://www.destatis.de/DE/ 
Presse/Pressemitteilungen/2019/11/PD19_453_213.html. Accessed 4 Oct 2020

48. Destatis (2020) 2019 voraussichtlich geringstes Bevölkerungswachstum seit 2012. Press release No. 22, 17 Januar 2020, German Federal Office of Statistics, https://www.destatis.de/DE/Presse/Pressemitteilun gen/2020/01/PD20_022_12411.html. Accessed 4 Oct 2020

49. US Census (2018) More Than 76 Million Students Enrolled in U.S. Schools, Census Bureau Reports. Release Number CB18-192 from 11 December 2018 https://www.census.gov/newsroom/press-relea ses/2018/school-enrollment.html. Accessed 4 Oct 2020

50. ETH (2004) Umwelt- und Energiereport 2004. https://ethz.ch/content/ dam/ethz/common/docs/publications/sustainability/ETH-UmweltEner gieReport_2004.pdf. Accessed 6 Jan 2021

51. King's (2021a) Carbon. https://www.kcl.ac.uk/aboutkings/strategy/susta inability/policies-strategies/carbon/carbon. Accessed 6 Jan 2021

52. King's (2021b) Sustainability Champions. https://www.kcl.ac.uk/about kings/strategy/sustainability/get-involved/staff/sustainability-champ ions/sustainability-champions. Accessed 6 Jan 2021

53. EU (2020) Committing to climate-neutrality by 2050: Commission proposes European Climate Law and consults on the European Climate Pact. Press release IP/20/335, Brussels, 4 March 2020. https://ec.europ a.eu/commission/presscorner/api/files/document/print/en/ip_20_335/ IP_20_335_EN.pdf. Accessed 4 Oct 2020

54. Rogelj J, Schaeffer M, Meinshausen M, Knutti R, Alcamo J, Riahi K, Hare W (2015) Zero emission targets as long-term global goals for climate protection. Environ Res Lett 10:105007. https://doi.org/10.1088/17489326/10/10/105007

55. Lichtblick (2020) Schwimmt mal mit dem Strom - dem ÖkoStrom. https://www.lichtblick.de/oekostrom/?sl_type $=4 \&$ lbm_csi=stromtarif \&gclid=CjOKCQiAlsv_BRDtARIsAHMGVSYkOjaymFcPLgMLIbSyWUL 3L52rJIB1nhsY6UnRbBsm-6vo4ITzrYAaAk2IEALw_wcB. Accessed 4 Jan 2021

56. IPCC (2014) Energy systems. In: Climate change 2014: mitigation of climate change. contribution of working group III to the Fifth Assessment Report of the Intergovernmental Panel on Climate Change. https ://www.ipcc.ch/pdf/assessment-report/ar5/wg3/ipcc_wg3_ar5_chapt er7.pdf. Accessed 5 Oct 2020

57. UNFCCC (2019) CDM Methodology booklet. Clean development mechanism. Eleventh edition, November 2019, pp 277. https://cdm. unfccc.int/methodologies/documentation/2003/CDM-Methodolog y-Booklet_fullversion.pdf. Accessed 5 Oct 2020

58. UMD (2020). University of Maryland climate action plan 2.0. https:// sustainability.umd.edu/progress/climate-action-plan. Accessed $25 \mathrm{Sept}$ 2020

59. Monash (2016) Monash University Annual report 2016. https://www. monash.edu/_data/assets/pdf_file/0011/844508/monash-university -2016-annual-report.pdf. Accessed 26 Sept 2020

60. UQ (2015) The University of Queensland UQ Sustainability Action Plan 2015, pp 27. https://sustainability.uq.edu.au/files/1197/UQ-SAP.pdf. Accessed 25 Sept 2020

61. Sgouridis S, Helmers E, Al Hadhrami M (2017) Light-duty electric vehicles in the Gulf. Techno-economic assessment and policy implications. Int J Sustain Transp. https://doi.org/10.1080/15568318.2017.1332256

62. Umweltbundesamt (2018) Freiwillige $\mathrm{CO}_{2}$-Kompensation durch Klimaschutzprojekte. Report, German Federal Environment Agency, pp 44, July 2018. https://www.umweltbundesamt.de/sites/default/files/medie n/376/publikationen/ratgeber_freiwillige_co2_kompensation_final _internet.pdf. Accessed 5 Oct 2020

63. Schwartzkopf L, Urban G (2019) Minnesota State University (Mankato) Carbon Footprint Update Report 2018. September 23, 2019. report https://mankato.mnsu.edu/globalassets/finance-and-administration/ greencampus/carbonfootprint/minnesota-state-mankato-carbo n-footprint-update-report-2018-final.pdf. Accessed 25 Sept 2020

64. Metha P, Chang CC, Thoung G, Dauwels J, Wu X, Chien SC, Menoth DM, Helmers E (2021) Time trend analysis of operational carbon emissions and efforts to achieve campus carbon reduction: a case study at Nanyang Technological University (NTU), Singapore. Submitted

65. Gielen D, Boshell F, Saygin D, Bazilian MD, Wagner N, Gorini R (2019) The role of renewable energy in the global energy transformation. Energy Strategy Rev 24:38-50. https://doi.org/10.1016/j.esr.2019.01.006
66. Sgouridis S, Csala D, Bardi U (2016) The sower's way: quantifying the narrowing net-energy pathways to a global energy transition. Environ Res Lett 11:094009. https://doi.org/10.1088/1748-9326/11/9/094009

67. Moriarty P, Honnery D (2019) Energy accounting for a renewable energy future. Energies 12:4280. https://doi.org/10.3390/en12224280

68. GEMIS (2008) Global emission model of integrated systems (GEMIS): manual. http://www.iinas.org/tl_files/iinas/downloads/GEMIS/2008_ g45_manual.pdf. Accessed 4 Jan 2021

69. ProBas (2021) Beschreibung des ProBas-Datenbankformats. https:// www.probas.umweltbundesamt.de/download/datenbankdefinition4 xls. Accessed 4 Jan 2021

70. GEMIS (2020) Global emissions model for integrated systems. Free database, http://iinas.org/gemis.html. Accessed 5 Oct 2020

71. Fthenakis VM, Kim HC, Alsema E (2008) Emissions from Photovoltaic Life Cycles. Environ Sci Technol 42(6):2168-2174. https://doi.org/10.1021/ es071763a

72. ProBas (2020b) ProBas Prozessorientierte Basisdaten für Umweltmanagementsysteme. Free database, German Federal Environment Agency. https://www.probas.umweltbundesamt.de/php/index.php. Accessed 5 Oct 2020

73. Ghimire SR, Johnston JM, Ingwersen WW, Sojka S (2017) Life cycle assessment of a commercial rainwater harvesting system compared with a municipal water supply system. J Clean Prod 151:74-86. https:// doi.org/10.1016/j.jclepro.2017.02.025

74. Defra (2017) United Kingdom, Department for Environment, Food \& Rural Affairs. Greenhouse gas reporting: conversion factors 2017-condensed set. https://assets.publishing.service.gov.uk/government/uploa ds/system/uploads/attachment_data/file/635632/Conversion_facto rs_2017__CCondensed_set_for most users v02-00.xls. Accessed 15 Oct 2020

75. Preton (2020) Preton Print and save. Drucken und Umwelt-Informationen. http://174.129.237.94/PDF/Drucken-Umwelt-Informationen.pdf. Accessed 15 Oct 2020

76. ProBas (2020a) Prozessdetails: Flugzeug-Passagiere-internantionalDE-2010. https://www.probas.umweltbundesamt.de/php/prozessdet ails.php?id=\%7bAE2A03EE-1342-4C12-8185-1EB7F997290D\%7d .Accessed 22 Sept 2020

77. UCT (2020) Student support—University of Cape Town. http://www. iapo.uct.ac.za/iapo/app/acc. Accessed 4 Sept 2020

78. Abdul-Azeez IA, Ho CS (2015) Realizing low carbon emission in the university campus towards energy sustainability. Open J Energy Efficiency 4:15-27. https://doi.org/10.4236/ojee.2015.42002

79. Umweltbundesamt (2020) Strom- und Wärmeversorgung in Zahlen. German Federal Environment Agency https://www.umweltbundesamt de/themen/klima-energie/energieversorgung/strom-waermevers orgung-in-zahlen\#Kraftwerke. Accessed 27 Sept 2020

80. Yale (2020) Financial reports. https://your.yale.edu/work-yale/financialmanagement/accounting/financial-reports. Accessed 29 Dec 2020

81. De Montfort University (2010) ANNUAL ACCOUNTS, 2009, 2010. https:// www.dmu.ac.uk/documents/about-dmu-documents/university-gover nance/annual-reports/dmu-annual-accounts-2009-2010.pdf. Accessed 29 Dec 2020

82. Duquesne University (2019) FACT BOOK 2018-2019 https://duq.edu/ assets/Documents/institutional-research/_pdf/fact-book/2018-19\%20 Fact\%20Book\%20WEB\%20Institutional\%20Data.pdf. Accessed 29 Dec 2020

83. ETH (2017) ETH Zürich Annual report 2017. https://ethz.ch/content/ dam/ethz/main/eth-zurich/Informationsmaterial/GB17/01_ETH_GB17_ EN_low.pdf. Accessed 29 Dec 2020

84. King's (2018) Financial Statements for the year to 31 July 2018. https:// www.kcl.ac.uk/aboutkings/orgstructure/ps/finance/statements/finan cialstatments2018.pdf. Accessed 29 Dec 2020

85. Leuphana (2015) Leuphana Universität Lüneburg Stiftung des öffentlichen Rechts: Jahresabschluss und Lagebericht für das Geschäftssjahr 2015. Bestätigungsvermerk des Abschlussprüfers. https://www.leuph ana.de/fileadmin/user_upload/organisation/files/Leuphana_Jahresabsc hluss_Lagebericht_Geschaeftsjahr_2015.pdf. Accessed 30 Dec 2020

86. Minnesota State University (2020) Data USA: Minnesota State University-Mankato https://datausa.io/profile/university/minnesota-state -university-mankato\#operations. Accessed 29 Dec 2020 
87. Monash university (2016) Annual report 2016. https://www.monas h.edu/_data/assets/pdf_file/0011/844508/monash-university-2016annual-report.pdf. Accessed 29 Dec 2020

88. NTU (2017) Nanyang Technological University - The next wave. Annual report 2017. https://www3.ntu.edu.sg/CorpComms2/AnnualRepo rt/2017/index.html\#p=1. Accessed 29 Dec 2020

89. Tongji University (2020) Facts and figures. https://en.tongji.edu.cn/ About/Facts_and_Figures.htm. Accessed 28 Dec 2020

90. Universidad Talca (2016) Reporte 2016 de Sustentabilidad. https://issuu .com/rsu_utalca/docs/gri_2016. Accessed 29 Dec 2020

91. Universiti Teknologi Malaysia (2011) Laporan Tahunan. https://corpo rateaffairs.utm.my/corporatepublication/wp-content/uploads/sites /9/2019/02/Lap-Tahunan-UTM-2011.pdf. Accessed 29 Dec 2020

92. University College Cork (2018) University College Cork National University of Ireland, Cork: Consolidated Financial Statements Year Ended 30 September 2028. https://www.ucc.ie/en/media/support/financeoff ice/financialaccounting/2018FinancialStatementsEnglishVersion.pdf. Accessed 29 Dec 2020

93. University of Cape Town (2013) Annual report and annual financial statements 2013 http://www.staff.uct.ac.za/sites/default/files/image_ tool/images/431/finance/operations/statements/afs2013.pdf. Accessed 29 Dec 2020

94. University of Maryland (2018) FY 2018 total operating budget: expenditures http://otcads.umd.edu/bfa/FY18\%20Working\%20Budget/Web/ FY18\%20EXP\%20\%20-\%20Cat\%20web.pdf. Accessed 29 Dec 2020

95. University of Queensland (2016) Summary of financial information. https://about.uq.edu.au/files/4829/3_Key\%20Statistics\%20and\%20Fin ancial\%20Information.pdf. Accessed 29 Dec 2020

96. Universität Potsdam (2019) Aktuelle Daten der Universität Potsdam 2019. https://www.uni-potsdam.de/fileadmin/projects/verwaltung/ docs/Dezernat1/Statistiken/UP-AKT.pdf. Accessed 29 Dec 2020

97. Macrotrends (2020) US Dollar - Singapore Exchange Rate - Historical Chart. https://www.macrotrends.net/2561/us-dollar-singapore-excha nge-rate-historical-chart. Accessed 27 Dec 2020

98. Finanzen (2020) Euro-Malaysischer Ringgit (EUR-MYR)—Historische Kurse. https://www.finanzen.net/devisen/euro-malaysischer_ringg it-kurs/historisch. Accessed 17 Dec 2020
99. OECD (2020) Exchange rates. https://data.oecd.org/conversion/excha nge-rates.htm\#indicator-chart. Accessed 27 Dec 2020

100. Yanez P, Arijit Sinha A, Vásquez M (2020) Carbon footprint estimation in a university campus: evaluation and insights. Sustainability 12:181. https://doi.org/10.3390/su12010181

101. Stars (2018) University College Cork-National University of Ireland, Cork. OP-1: Greenhouse Gas Emissions. https://reports.aashe.org/insti tutions/university-college-cork-national-university-of-ireland-cork-cocorcaigh/report/2018-07-20/OP/air-climate/OP-1/. Accessed 27 Sept 2020

102. UP (2019) University of Potsdam Klimaschutzkonzept, pp 99. https:// www.uni-potsdam.de/fileadmin/projects/umweltportal/pdf/191209_ ARC_U_Klimaschutzkonzept_der_Universtitat_final.pdf. https://www. uni-potsdam.de/fileadmin/projects/verwaltung/docs/Dezernat1/Stati stiken/UP-AKT.pdf. Accessed 27 Sept 2020

103. KU (2014) Sustainability at KU Leuven 2014-2017. https://www.kuleu ven.be/duurzaamheid/sustainability/doc/sustainability-at-ku-leuve n-2014-2017.pdf. Accessed 27 Sept 2020

104. Yale (2016) Yale university Greenhouse gas emissions reduction progress-2016, pp 2. https://sustainability.yale.edu/resources/green house-gas-emissions-reduction-progress-2016. Accessed 26 Sept 2020

105. Ellert A (2019) One step at a time: Duquesne University's Seventh Greenhouse gas emissions inventory. https://www.duq.edu/assets/ Documents/environmental-science/_pdf/Greenhouse\%20Gas/2016_ GHG-Emissions_report_p2019a.pdf. Accessed 25 Sept 2020

106. Spirovski D, Abazi A, Iljazi I, Ismaili M, Cassulo G, Venturin A (2012) Realization of a low emission university campus trough the implementation of a climate action plan. Procedia Soc Behav Sci 46:4695-4702. https:// doi.org/10.1016/j.sbspro.2012.06.321

\section{Publisher's Note}

Springer Nature remains neutral with regard to jurisdictional claims in published maps and institutional affiliations.

\section{Submit your manuscript to a SpringerOpen ${ }^{\circ}$ journal and benefit from:}

- Convenient online submission

- Rigorous peer review

- Open access: articles freely available online

- High visibility within the field

- Retaining the copyright to your article

Submit your next manuscript at springeropen.com 